Essay

\title{
Energy Re-Shift for an Urbanizing World
}

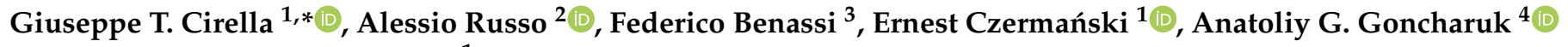 \\ and Aneta Oniszczuk-Jastrzabek ${ }^{1}$
}

1 Faculty of Economics, University of Gdansk, 81-824 Sopot, Poland; ernest.czermanski@ug.edu.pl (E.C.); aneta.oniszczuk-jastrzabek@ug.edu.pl (A.O.-J.)

2 School of Arts, University of Gloucestershire, Cheltenham GL50 4AZ, UK; arusso@glos.ac.uk

3 Italian National Institute of Statistics, 00144 Rome, Italy; benassi@istat.it

4 Department of Management, International Humanitarian University, 65009 Odessa, Ukraine; agg@ua.fm

* Correspondence: gt.cirella@ug.edu.pl; Tel.: +48-58-523-1258

Citation: Cirella, G.T.; Russo, A.;

Benassi, F.; Czermański, E.;

Goncharuk, A.G.; Oniszczuk-

Jastrzabek, A. Energy Re-Shift for an

Urbanizing World. Energies 2021, 14,

5516. https://doi.org/10.3390/

en14175516

Academic Editor: Donato Morea

Received: 23 July 2021

Accepted: 31 August 2021

Published: 3 September 2021

Publisher's Note: MDPI stays neutral with regard to jurisdictional claims in published maps and institutional affiliations.

Copyright: (C) 2021 by the authors. Licensee MDPI, Basel, Switzerland. This article is an open access article distributed under the terms and conditions of the Creative Commons Attribution (CC BY) license (https:// creativecommons.org/licenses/by/ $4.0 /)$.

\begin{abstract}
This essay considers the rural-to-urban transition and correlates it with urban energy demands. Three distinct themes are inspected and interrelated to develop awareness for an urbanizing world: internal urban design and innovation, technical transition, and geopolitical change. Data were collected on the use of energy in cities and, by extension, nation states over the last 30 years. The urban population boom continues to pressure the energy dimension with heavily weighted impacts on less developed regions. Sustainable urban energy will need to reduce resource inputs and environmental impacts and decouple economic growth from energy consumption. Fossil fuels continue to be the preferred method of energy for cities; however, an increased understanding is emerging that sustainable energy forms can be implemented as alternatives. Key to this transition will be the will to invest in renewables (i.e., solar, wind, hydro, tidal, geothermal, and biomass), efficient infrastructure, and smart eco-city designs. This essay elucidates how the technical transition of energy-friendly technologies focuses on understanding the changes in the energy mix from non-renewable to renewable. Smart electricity storage grids with artificial intelligence can operate internationally and alleviate some geopolitical barriers. Energy politics is shown to be a problematic hurdle with case research examples specific to Central and Eastern Europe. The energy re-shift stressed is a philosophical re-thinking of modern cities as well as a new approach to the human-energy relationship.
\end{abstract}

Keywords: rural-to-urban transition; energy mitigation; urbanization agenda; smart city; energy landscape; urban energy transition; alternative energy technologies; sustainable energy; geopolitical energy change; Central and Eastern Europe

\section{Introduction}

The year 2007 marked a fundamental phase in human history: half of the world, for the first time, became urbanized [1]. A change so important that it has been juxtaposed with other fundamental steps in our evolution, such as the agricultural and industrial revolutions, thus coining a new anthropological term, homo urbanus [2]. It is a development that does not seem destined to stop, since the latest available data indicate that in 2018 the percentage of urban population (i.e., globally) has risen to $55 \%$, a share that will exceed, according to official forecasts, $68 \%$ in 2050 [3-5]. An even more radical change if we consider that in 1950 the percentage of rural population was 70\%. It is not by chance, therefore, that cities have progressively assumed a more central role in the economy, aided by the process of economic globalization [6], and that they represent, for some, the greatest human invention [7-9]. Urbanization, in fact, is not new but rather a process that has accompanied human beings since their birth, significantly characterizing their social and economic circumstances [10]. However, it is only since the nineteenth and twentieth centuries that we can speak of "urbanized societies" [11]. The shift from rural to urban has been accompanied, in today's advanced development economies, by the shift from 
societies characterized by high levels of birth and mortality to societies in which these two endogenous forces are both at low levels. These profound transformations, which in many developing countries are still in progress, are grounded in the theory of demographic transition [12] and that of mobility [13]. Together with these transitions, economic and social development has taken place, i.e., the so-called modernization era [14]. The interconnections between rural-to-urban transition and economic development are well known; e.g., in $2015,80 \%$ of the global gross domestic product (GDP) was generated in cities [15]. These are even clearer if we think of the deep differentiations that exist, and will persist, between advanced and developing countries, precisely in relation to urban population growth processes [16]. According to official data from the United Nations, in 2018 the percentage of urban population was about 79\% in more developed regions (MDRs), while it was almost $51 \%$ in less developed regions (LDRs); in 1950, these shares were $55 \%$ and $18 \%$, and it is estimated that they will become about $87 \%$ and $66 \%$ in 2050 , respectively [1]. The world is and will thus inexorably be increasingly urban. There is therefore a need to govern this transition constructively and sustainably by not allowing such processes to rule over us.

Historically, the driving force behind urbanization has been migration. In fact, urban population growth is achieved mainly through migration mechanisms, i.e., the different capacity of cities to attract non-urban populations, rather than on the different levels of natural growth of urban and non-urban populations [17]. From a theoretical point of view, the process of urbanization and, more generally, of urban development can be seen as a combination of incoming and outgoing movements. The former is defined as centripetal and concerns rural-urban migration, gentrification, re-urbanization, and urban sprawl renewal. In contrast, the latter is known as centrifugal and refers to suburbanization, urban sprawl, and counterurbanization. Of course, these types of categorizations can vary greatly if we consider the level of development of observed countries and regions [18]. But what will this inexorable process of urbanization mean for the environment, for health, for sustainability, and in terms of energy? Opinions are varied and much will depend on which energy and environmental profiles cities associate themselves with. It is a question of considering urban growth as an opportunity and not as a cost. At present, especially in LDRs, migration towards cities along the rural-urban axis is interconnected with environmental processes, such as desertification and climate change, that these same megacities and large conurbations help to reinforce through the pollution they cyclically produce and trigger. Moreover, if the increase in cities could determine positive externalities [15], the negative externalities that deregulated urbanization processes-defined in the literature as spontaneous, at best, and wild, at worst-can determine the health, urban microclimate, and general conditions of human habitation of urban environments [19,20].

A relevant issue is obviously the energy dimension and its design and management with respect to urban development, both in progress and, above all, in the future, which, as we have pointed out, will largely impact LDRs. Many contributions have been devoted to this issue [21-23]. In particular, in a recent paper that appeared in the UN Chronicle by Philipps and Smith [24], it is clearly stated that "sustainable urban energy is the future." They argue that the implementation of renewable energy strategies in urban environments has become energy impartial, e.g., through a change of sources, but also by ensuring they are actually sustainable and cost-effective. In particular, the point that needs to be emphasized is that the next, inevitable, phase of urban growth, especially in LDRs, must favor processes of environmental sustainability, thus interrupting the vicious cyclic processes that are not sustainable in the medium to long term. The key points, in this regard, on which to invest resources should include solar power, efficient infrastructure, and ecocities. The process of urbanization is challenging, but we believe it is also an opportunity. From this point of view, cities, and countries by extension, can represent advantages [25] for urban environmental services via effective energy mitigation strategies. This essay expands on the notion of an urbanizing world and focuses on three points of understanding this phenomenon: (1) internal (i.e., from a smart city design and techno-innovative perspective), 
(2) technical (i.e., from a mitigative transitory outlook), and (3) geopolitical (i.e., from our ability to change and get along as nation states using Central and Eastern Europe as case research).

\section{Materials and Methods}

This is an expository essay that provides a focused explanation of the energy reshift for an urbanizing world and correlates this viewpoint with urban energy needs. The methodology for the essay is desk-based research. Data were collected on the use of energy in cities and, by extension, nation states within the context of the essay's three subject matters-i.e., internal urban design and innovation, technical transition, and geopolitical change-over the last 30 years (1991-2021). Urban-centric data focused on smart city design techniques, energy alternatives, and renewables. Specific case research from Central and Eastern Europe is used to stress the economic re-shift of energy markets and their potential for energy poverty and geopolitical shifts. We analyze how these differences affected energy development and sustainability in the context of the rural-to-urban transition. After which, the main challenge is to consider, in the short and medium terms, if the current policies for energy development and use are viable in an urban and regional context.

A scoping literature search was completed using the following electronic resources: Web of Knowledge, Scopus, Science Direct, Google Scholar, and Google. The study synthesized exploratory keywords aimed at mapping key concepts, types of evidence, and gaps in the research by systematically searching, selecting, and synthesizing existing knowledge. Explanatory keywords were derived by using a combined star busting [26] and brainstorming [27] approach, as well as the stepladder method of accumulating additional keywords as research was found [28] (see Appendix A for a list of keywords utilized in the analysis). The literature was compiled and publications were systematically analyzed using strategic and critical reading methods $[29,30]$, as presented in Table A1. We identified more than 3000 articles and grey literature in the first step of the search. To better focus on the essay's three subject matters, we filtered out literature published before 1991 and omitted literature discussing rural-related research as well as narrow technological and engineering-based perspectives, leaving approximately 200 publications in the form of books, scientific articles, and technical reports. Corresponding references, cited in the text, are detailed as data sources and based on the analyses and know-how of the scientific experts of each studied theme. Based on all these materials, a set of proposals to develop internal, technical, and geopolitical backing was formulated to uphold the urbanization agenda and to mitigate energy sustainability strategies.

\section{Results and Discussion}

\subsection{Smart City Landscape Design and Energy Innovation: Internal Urban Strategies}

To solve the two worldwide environmental concerns of urbanization and rising carbon dioxide $\left(\mathrm{CO}_{2}\right)$ emissions, a smart and urban energy transition is needed [31]. The "smart" approach to urbanism and city development has sparked controversy in sectors such as engineering, innovation, and the social sciences [32]. While sustainability is not often a primary goal of local smart city implementation, the smart agenda raises the bar for achieving energy sustainability goals [32]. Hence, the energy system is one of the most important components of a smart city, as it plays a critical part in the transition to a more sustainable urban lifestyle [33]. The use of renewable energy sources is shown to make a major contribution to lowering pollutant emissions and improving living environment quality [33]. A variety of components and environmentally friendly elements must be integrated for cities to have smart energy systems. The energy systems that provide these cities with heating, cooling, and electricity must be clean, renewable, and abundant, as well as efficient, effective, and secure [34]. However, smart cities are rarely discussed in academic research in the fields of landscape architecture, urban design, and planning [35]. The main function of urban and landscape design in the building of the smart city is based on the integration of technology components with the physical city, including residence 
and public spaces, politics, economy, and ecology, among other things [35]. The spatial patterns of urban energy systems evident in the built environment are represented by urban energy landscapes [31]. In urban energy landscapes, spatial regularities in the organization of energy provision and consumption systems are visible [31]. The built environment's architecture, as well as people's views of technology, may influence how much energy is used [31]. In this context, renewable energy and green infrastructure will play a crucial role in the development of smart and sustainable cities [36]. However, wind turbines and solar panels are not enough to make the shift from fossil fuel to renewable energy [37]. Landscape design, for instance, can help to reduce periodic variations in energy supply as well as low energy density, which are two of renewable energy's main drawbacks [37]. Energyconscious planning and design may also increase the efficiency of available energy, whether it comes from renewable or non-renewable sources [37]. As such, a well-planned landscape saves energy and can pay back the initial expenditure in as little as eight years [38]. For example, by allowing winter sun in, an eight-foot deciduous tree may save hundreds of dollars in air conditioning expenditures while also lowering heating and lighting costs [38]. Energy conservation not only saves money but also benefits the environment by reducing the usage of natural resources [38]. Specific landscape design methods are determined by regional climatic conditions as well as the microclimate immediately around buildings [38].

Studies have shown that green infrastructure, which may be built or restored, might help to reduce an area's overall energy demand and, in doing so, help to mitigate the "urban heat island" effect [39]. By shading building surfaces, deflecting solar radiation, and releasing moisture into the environment, trees, green roofs, and other green infrastructure features can help to cool metropolitan environments [39]. In contrast to buildings without trees, a building with trees can consume $2.3 \%$ to $90 \%$ less cooling energy and $1 \%$ to $20 \%$ less heating energy due to windbreak effects [40]. In particular, shade from trees has a greater cooling impact than evapotranspiration from lawns, resulting in significant cooling load reduction [41]. Over 15 years, McPherson and Simpson [42] predicted that planting 50 million trees to shade the east and west sides of residential buildings in California would reduce cooling by $1.1 \%$ and peak load demand by $4.5 \%$. Moreover, green walls, green facades, and green roofs are examples of exterior greenery systems which can save energy as well as benefit the built environment [43,44]. In Arizona, Yuan and Rim [43] found that green walls can save up to $27,000 \mathrm{kWh} / \mathrm{y}$ at a primary school in Phoenix while a green roof can save up to $69,000 \mathrm{kWh} / \mathrm{y}$. In China, Tan et al. [45] investigated the energy-saving potential of building envelope integrated green plants (BIGP) in hot summer and cold winter climates, using comparison tests between a vertical greening room and a reference room. During the winter, BIGP reduced the heat flux density of the outside wall by $3.11 \mathrm{~W} / \mathrm{m}^{2}$, while the reference room's hourly power usage remained 1.22 times higher. BIGP conserved energy at a rate of about $18 \%$. During the summer, the heat flux density of the reference room's external wall was $4.15 \mathrm{~W} / \mathrm{m}^{2}$ higher than that of the vertical green room, with the hourly power usage being 1.33 times higher. It can be stated that BIGP saves roughly $25 \%$ of the energy it consumes. Modeling findings evaluated the cooling advantages of green areas in proportion to the mean height of buildings on Gulou Campus in Nanjing, China, yielding $5.2 \mathrm{~W} / \mathrm{m}^{2}$ of cooling energy and saving $1.3 \times 10^{4} \mathrm{~kW} / \mathrm{h}$ over a single daytime hot summer period, according to research by Kong et al. [46].

Green infrastructure can also be promoted as a low-cost strategy for mitigating the carbon footprint of industrial energy. For example, green infrastructure in Hangzhou, China offsets $18.57 \%$ of the carbon produced by industrial businesses each year through sequestration and stores an amount of carbon equivalent to 1.75 times the yearly carbon emitted by industrial energy consumption within the city [47]. Green infrastructure may also be a solution to several water-related issues originating from the energy sector. It may be used to enhance the energy efficiency of power generation, in addition to conserving the water environment and water supplies in general [48]. Green infrastructure, when combined with grey infrastructure, such as hydroelectric dams, can increase its lifetime and efficiency [48]. In addition, green infrastructure can be used for the production of biomass 
energy, even though it has a greater spatial footprint than other energy carriers (e.g., solar power). Important research is lacking on whether a significant increase in biomass use in cities is feasible [36]. Biomass can be used to produce energy from green infrastructure pruning and urban agriculture (e.g., via edible green infrastructure) but requires a substantial amount of (prolonged) maintenance. For example, in Milan, Ferla et al. [49] assessed the biomass of urban greenery maintenance from an energy perspective. They found a biomass potential energy between 26 and $76 \mathrm{GWh}$, relative to the green-based inventory, regulation, plan, and informatic system used to assay the research [49].

A good example of integration of green infrastructure and renewable energies is the Beddington Zero (fossil) Energy Development (BedZED) in the London Borough of Sutton, United Kingdom (Figure 1). Its major accomplishments include the integration of infrastructure systems for synergistic efficiencies, the installation of renewable energy infrastructure (e.g., from the sun and wind), and the closure of various energy and water loops [50]. In their analyses, the planners and designers of these infrastructures took into account the life cycles of various systems and processes [50]. BedZED was designed to have a low environmental impact during construction and operation, allowing residents to live within their fair share of the earth's resources. Hodge and Haltrecht [51] point out some of the key operational goals of the design:

- reduce water consumption by $33 \%$ compared to the national average,

- reduce electricity consumption by $33 \%$ compared to the national average,

- reduce space heating requirements by $90 \%$ compared to the national average,

- $\quad$ reduce private fossil-fuel car mileage to $50 \%$ of the national average, and

- eliminate $\mathrm{CO}_{2}$ emissions from energy consumption [51].

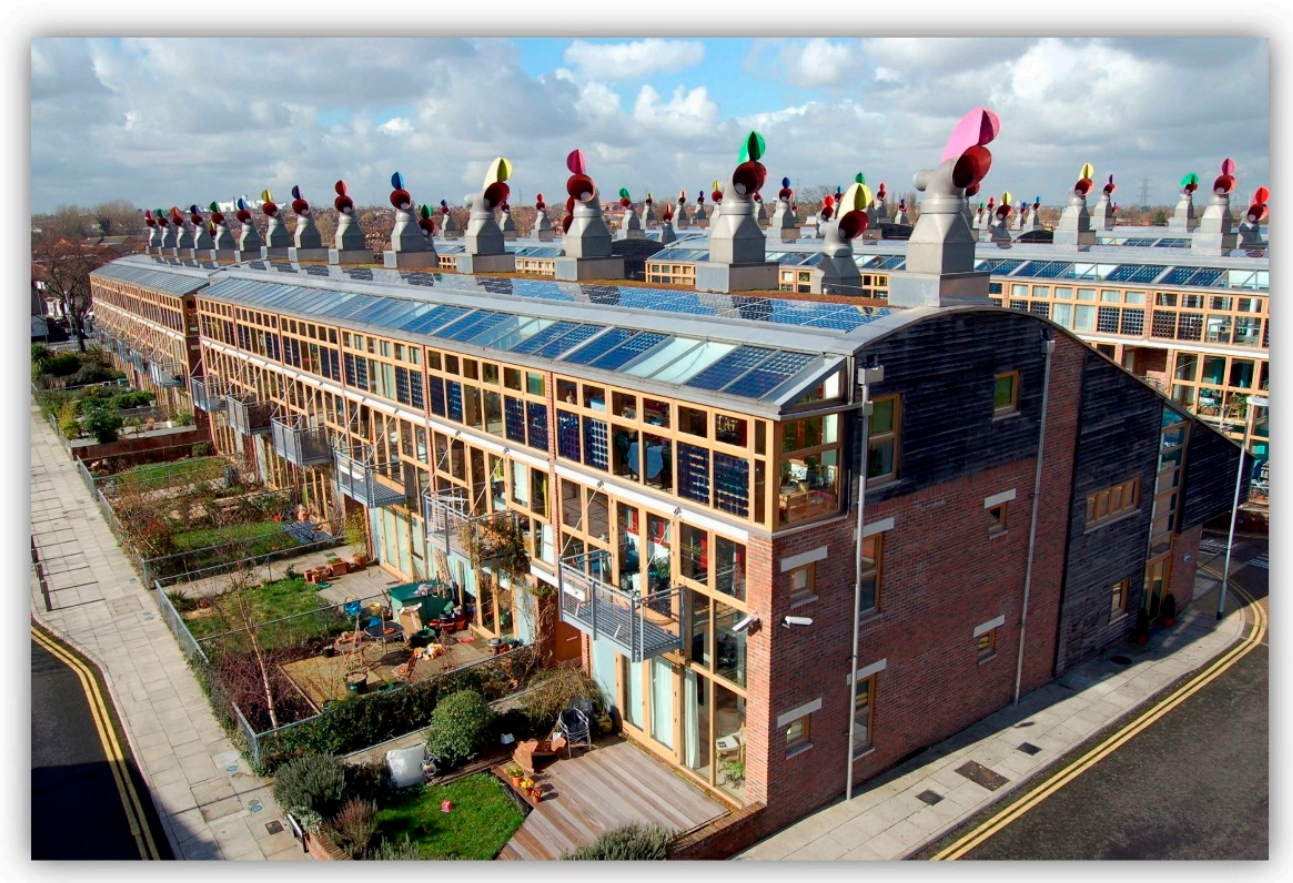

Figure 1. BedZED project in Hackbridge, London borough of Sutton, with solar panels, wind cowls, and green roofs. Source: Image credits Tom Chance https:/ / www.flickr.com/photos/tomchance/10 08213420 / CC BY 2.0, accessed on 22 July 2021.

BedZED households use $2579 \mathrm{kWh}$ of electricity per year, which is $45 \%$ less than the Sutton average. BedZED uses gas to power the district's heating system when the biomass combined heat and power (CHP) plant is not in use. Households use $3526 \mathrm{kWh}$ of heat (e.g., from gas) per year on average, which is $81 \%$ less than the Sutton average [51]. The prototype CHP unit from BedZED was designed to be completely automated, with unattended start-up and shut-down and stringent, automatically controlled operational 
parameters. The plant is planned to work $24 \mathrm{~h}$ a day, seven days a week; however, because of noise limits of $37 \mathrm{dBA}$ at $20 \mathrm{~m}$, it only runs for $18 \mathrm{~h}$ per day [51]. In addition, on the rooftops and in the south-facing second floor windows, there are $777 \mathrm{~m}^{2}$ of photovoltaic panels made up of 1138 laminates as well as garden roofs that provide several ecosystem services [51].

The European Green Deal (i.e., the European Union's most significant step toward climate neutrality, issued at the end of 2019) as well the recent European COVID-19 Recovery Fund, represent an opportunity to accelerate the development of renewable energies and green infrastructure-based projects in European cities [52]. Moreover, smart information and communication technology, in combination with urban green infrastructure planning concepts, could be a powerful instrument for coordinating and managing energy issues and the bettering of sustainable smart cities [35]. To navigate this, there will be the need for a technical transition within the urban energy grid that focalizes on non-renewable to renewable forms, something that is fast occurring in much of the MDRs of the world.

\subsection{Technical Transition of Energy-Friendly Technologies: Urban Energy Mitigation from Non-Renewable to Renewable}

The path of sustainable development will certainly lead to changes in the energy mix from non-renewables towards 100\% renewables (i.e., solar, wind, hydro, tidal, geothermal, and biomass). On land and specifically in urban centers, this is possible with the development of appropriate models that are based not on generating facilities and a distribution network, but on storage systems and feedback loops into the distribution grid at times of temporary reduction in supply. A far-reaching concept is the use of smart grids (i.e., defined as artificially intelligent) and advanced power grids that are sustainability-oriented and energy efficient within a smart city design [53]. This type of urban energy landscape will internationally distribute and store electricity, and balance production and transmission volumes in relation to consumption needs [54]. To date, this concept exists in terms of electricity storage based on different types of battery and capacitor systems, even though at present the technology bears limited capacity and limited lifetime. Energy consumption itself varies greatly in space and time (e.g., on a daily, weekly, and annual basis), and does not coincide with any potential seasonality of renewable energy production. As a result, differences should be covered by energy storage systems [55-57] until better technological innovation can be achieved. Currently, known technologies require the use of lithium and cobalt and, as of 2021, the resources of these elements (i.e., in the form of various types of minerals) are not sufficient to cover the demand for the production of batteries for all-energy storage needs [58].

Another challenge is low resilience (i.e., intermittence and unpredictability) of solar and wind energies, which are not available every day or hour. These alternatives are also vulnerable to changes in weather conditions and, in the case of solar, after the complete life cycle of solar modules environmental, safety, and health concerns arise via their disposal [59]. Even though these and other challenges constrain the development of alternative energy-maintaining fossil fuels as the lead energy source worldwide, technological breakthroughs that sharply reduce the cost of specific investments can significantly accelerate the pace of their development and advancement into the main power grid. However, it should be stated, there is no lack of energy from renewables nor are they in short supply. Solar power alone could produce $3.1 \times 10^{17} \mathrm{kWh}$ per year with an annual global energy demand of $1.6 \times 10^{14} \mathrm{kWh}$ [60-62]. Moreover, the solar redesign of cities could include the expansion of solar panels to other parts of the cityscape other than the tops of buildings, e.g., solar pavement $[63,64]$, solar windows $[65,66]$, and solar farms located in and out of city limits (as found throughout many parts of Spain [67]). Currently, the world's largest renewable energy hub, the Western Green Energy Hub (WGEH) in Western Australia, plans to mix solar and wind and is poised to match Australia's entire energy fleet, contributing a whopping $50 \mathrm{GW}$ in power generation. WGEH is planned to be finalized by 2028 and is set to cost USD 95 billion, spanning $15,000 \mathrm{~km}^{2}$ [68]. 
In addition to the issue of electricity storage, alternative fuels such as liquid hydrogen or methanol can be used as energy carriers. Both of these fuels can be produced using conventional electricity. However, their use in the context of sustainable development implies that they should be produced using only renewable sources. To put it simply, producing hydrogen requires water and electricity for its electrolysis, whilst producing methanol requires $\mathrm{CO}_{2}$ (which human beings are increasingly supplying) and electricity. Regardless of the process of transforming the sources of energy consumed in cities, there is a clear process for reducing energy demand. Since $75 \%$ of the global greenhouse gas (GHG) emissions are sourced from the urban landscape, urban energy mitigation has become a serious part of the emission reduction process. Urban energy mitigation is complex. It is entrenched in two basic principles: (1) reduce the demand for energy by consumers and (2) change the energy to a clean-oriented source. This is noted, for example, in the recent changes to the German Federal Ministry for Economic Cooperation and Development's [69] report "Climate Change Mitigation in Cities: Urban Action to Reduce Greenhouse Gas Emissions," in which six sectors of urban energy mitigation exist: urban planning, buildings, transport and mobility, energy, waste, and water and sewage management. From this report, buildings (i.e., commercial, institutional, industrial, and residential) make up a $63 \%$ share of GHG emissions, with transport and mobility second at $28 \%$ (Figure 2). Another comprehensive study delivered by the consortium of the World Resources Institute, C40 Cities Climate Leadership Group, and ICLEI-Local Governments for Sustainability [70] defines these six sectors as: stationary energy; transportation; waste; industrial processes and product use; agriculture, forestry, and other land use; and any other emissions occurring outside the geographic boundary as a result of city activities. Regardless of the classification, it is crucial to develop and disseminate measures, actions, and solutions that lead to the highest possible reduction in urban emission pollution. This practice, however, is spatially limited and dependent on a number of local factors and conditions. The most frequently mentioned include:

- land use limitation for urban purposes by smart and compact designing of the public space,

- resource efficient modernization and new construction of buildings towards green building and climate-neutrality,

- $\quad$ smart and sustainable urban mobility leading to a more sustainable share for pedestrians and shared mobility users as well as public transport passengers, in return for a reduction in car users [28,71],

- postulated decentralization of renewable energy supply (i.e., mainly based on solar photovoltaics),

- improvement of solid waste and water and sewage management (i.e., the 3R strategy: reduce, reuse, and recycle) or a complementary waste-to-energy model-based city economy, and

- reviewing the energy mix while increasing the share from renewable sources.

To better understand the technological energy transition argument (and some would say urgency), emitted pollutants from cities are a driving force. Currently, the largest amount of potential reduction in GHG emissions comes from the energy sector in cities, i.e., $46 \%$ of all GHG emissions, wherein two-thirds is dedicated to electricity generation and the other third to fossil fuel extraction [72]. For example, within the transport sector, GHG emissions are estimated at 70\% from road, $20 \%$ from aviation, and $10 \%$ from shipping [72]. Since these figures provide valuable insight into the city-to-GHG emissions breakdown, solutions should start with or, at the minimum, include the reduction in emitted pollutants within the mitigatory process. In order to achieve GHG emissions reduction via energy mitigation, many cities worldwide have already introduced a wide range of solutions and measures related to all aspects of a city life. Some noteworthy urban energy mitigationbased studies include: (1) the United Nations Framework Convention on Climate Change's (UNFCCC) [73] report on the urban environment with related mitigation benefits and 
co-benefits of policies, practices, and actions; (2) the Intergovernmental Panel on Climate Change's [74] report on human settlements, infrastructure, and spatial planning; (3) C40 Cities et al.'s [72] report on the future of urban consumption in a $1.5^{\circ} \mathrm{C}$ world; (4) Santamouris et al.'s [75] research on heat mitigation technologies to improve sustainability in cities; (5) Santamouris et al.'s [76] work on the energy impact of urban heat island research in terms of climate and energy potential of mitigation technologies; (7) Zawadzka et al.'s [77] assessment of the heat mitigation capacity of urban greenspaces; and (8) Carbfix's [78] research outside of Reykjavik, Iceland, that can turn $\mathrm{CO}_{2}$ into stone [79]. The issue of urban energy mitigation shows a crucial relationship between the GHG emission reduction goal, which is key at the national and international level for determining which of the developed and implemented measures are subject to international legislation, and cities who, as major GHG emission contributors, are responsible for municipal scale activities introduced by city authorities. In combination, close cooperation between individual cities (often via umbrella organizations such as the C40 Cities Climate Leadership Group and ICLEI-Local Governments for Sustainability) and global bodies such as the United Nations can parallel their efforts, or work together, on the sustainable energy agenda (e.g., the City of Vancouver, Canada, Climate Emergency Action Plan [80] that resembles the United Nations Sustainable Development Goal 11 to make cities and human settlements inclusive, safe, resilient, and sustainable by 2030 [81]). Moreover, the UNFCCC Non-State Action Zone for Climate Action gathered information on 2578 cities from 118 countries representing $10.2 \%$ of the global population, and found that using energy initiatives as presented in Table A2 would reduce approximately $2.8 \mathrm{Gt}$ of $\mathrm{CO}_{2}$ emissions by 2050 [82] (Appendix B).

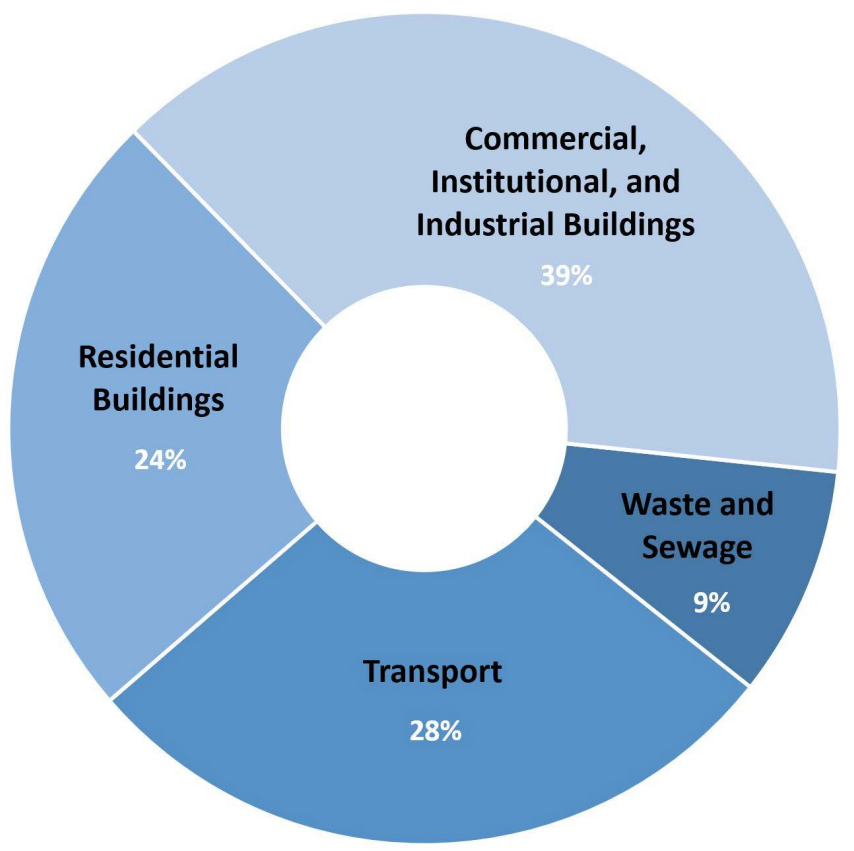

Figure 2. Share of GHG emissions in cities by sector, 2018. Source: German Federal Ministry for Economic Cooperation and Development [69].

The intricate phases of transitioning from non-renewable to renewable sources of energy are complex and no fixed solution is available. As noted, there are important city and international strategies that can aid in this ongoing transition. One important strategy worth noting is the cross-city partnership scheme, e.g., the Covenant of Mayors initiative, which interlinks thousands of municipalities who voluntarily commit to implementing European Union climate and energy objectives [83]. This urban energy mitigation initiative noticeably starts at the city scale, however, there is a global dialogue, i.e., with interlinking facets between international organizations, central governments and municipalities, and 
industry representatives, that can directly affect any country's energy mix. The elephant in the room we are referring to is the geopolitics of energy and its availability and distribution worldwide. Energy politics has increasingly come to a crossroads with the way cities and countries interact with each other and how citizens view potential energy needs.

\subsection{Geopolitical Energy Management and the Economic Re-Shift: Central and Eastern Europe Case Research}

Countries have been jostling and fighting over borders for as long as cities have existed. Civilizations have come and gone and formulate the precedent for how cities have developed. Today's geopolitical chessboard is very much rooted in this historical make up. Over the last decade, geo-economics and geopolitical processes are increasingly influencing energy management in various parts of the world. Military conflicts in the Middle East (e.g., Syria and Iraq [84] and the Arab-Israel conflict [85]), the crisis in Venezuela [86], China's growing energy demands $[87,88]$, and even the almost harmless blockade of the Suez Canal in March 2021 [89] have led to increased risks and higher energy prices. These price fluctuations are all interconnected to the energy politics of the day. For example, the linkages and energy collaboration between Iran [90], Russia [91], and Central Asian countries [92] can currently only partly satisfy the enormous energy appetite of China's growing economy [93], even with the outbreak from the COVID-19 pandemic. For example, in Iran, its primary barriers to solar energy development still remain economic, since it still faces heavy international sanctions in collaboration with the low price of fossil fuels [94]. In this case, the levelized cost of solar energy is still much higher than conventional technologies for electricity generation [95]. Moreover, the United States, with the transition from the Trump to Biden Administration, has somewhat eased pressure on Russia in terms of energy influence in the European Union [96]. This is expressed in a more loyal attitude from American authorities towards the completion of the construction of the Nord Stream 2 pipeline, a second Baltic Sea pipeline connecting Narva Bay, Russia, and Greifswald, Germany (Figure 3) [97]. Under the influence of such global shifts, the authorities of some of the most vulnerable countries, e.g., Ukraine, Poland, Slovakia, Belarus, and the Baltic states, are forced to revise their energy policies. A brief examination of the first two countries listed will showcase important examples of economic re-shifts in the region and exemplify the complexities of energy poverty at the city level and hard power at the international. The geopolitics of energy is obviously a vast and complex issue. Clearly, energy politics touches every country with no single solution. The examples used from Central and Eastern Europe exemplify the complexity and individuality of the energy problem each country faces, i.e., in securing its energy needs and ability to maneuver on the global chessboard between economics and energy resources.

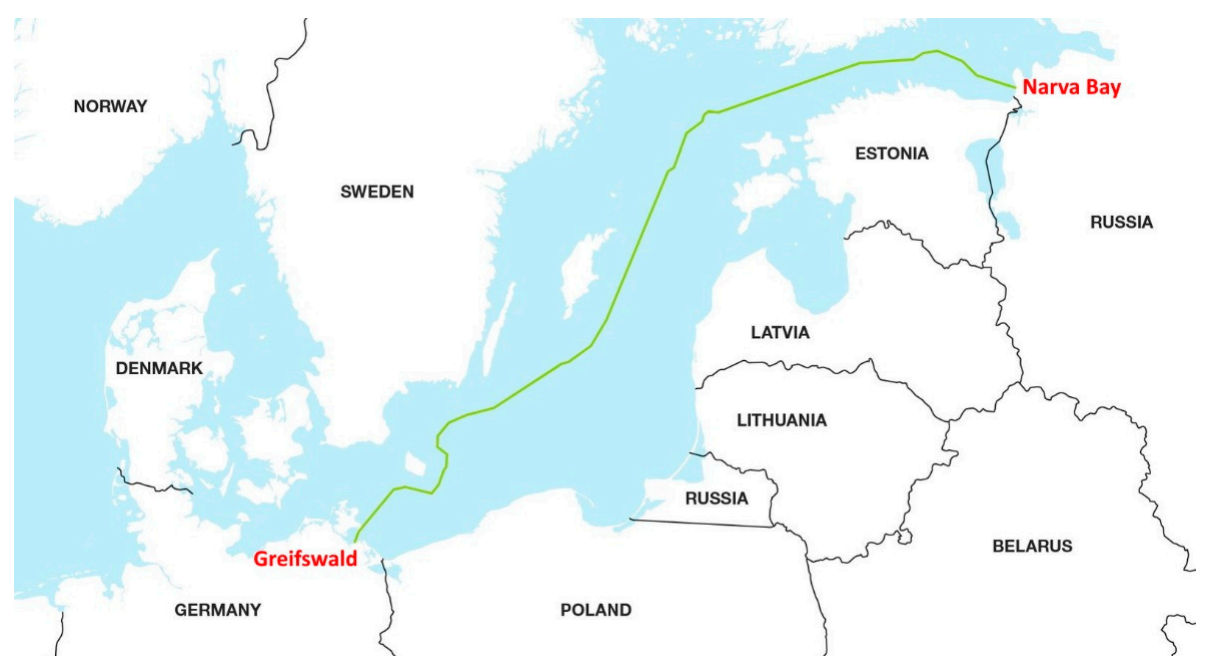

Figure 3. Nord Stream 2 pipeline. Source: Nord Stream 2 [98]. 


\subsubsection{Ukraine: Energy Hardship}

The launch of the Nord Stream 2 pipeline will leave the composition of natural gas suppliers to the European Union market essentially unchanged [99]; however, it will significantly weaken the position of Ukraine and its allied neighbors in energy and political independence from Russia. Furthermore, the completion of Nord Stream 2 may challenge the European Union's principles in terms of solidarity and trust [100], complicating the energy policy and management in Central and Eastern Europe and policy relations inside the Union itself. Central and Eastern European countries have an acute problem of energy poverty, in which about a fourth of the population is exposed to hidden energy shortages [101]. This is especially true in the case of Ukraine. This problem is sometimes exacerbated by the inadequate actions of the authorities at all levels of government. In Ukraine, where the problem of energy poverty has worsened due to the COVID-19 pandemic, the cost of energy resources in 2020 (despite being slightly economically cheaper) was that they were harder to utilize [102,103]. The expansion of the European Union's energy poverty policies, i.e., fueled by clean energy for all Europeans, as well as regulations and the creation of the European Union Energy Poverty Observatory and the ENGAGER project $[104,105]$, has begun to gradually address this problem, but there is still much to be done. An important factor for sustainability of energy management is alternative energy that can be diversified by varying countries, especially at the city level. Throughout much of Central and Eastern Europe, but especially in Ukraine, cities have been struggling to resolve a number of these barriers (i.e., economic, legal, sociocultural, technical, etc.) that can prevent prompt energy growth and development. In Ukraine, the share of renewables within the total energy mix is still very small. The continual dependence on traditional forms of energy interlocks its growing urban population with noticeable energy blackouts and shortages that hamper its development. Ukraine, as well as other Central and Eastern European countries, looks to the case of Poland as a prospective country that leads the region, as its energy industry has positively undergone comprehensive change in respect to the European Union's energy regulations, influencing energy transition towards climate neutrality, the aging coal stock of Poland's generating units, and increasing environmental awareness society-wide.

\subsubsection{Poland: Energy Advancement}

In Poland, the need to increase energy efficiency, in recent years, has resulted in energy needs going up-this has been simultaneous with climate change and the growth of customer preferences for energy-efficient products [106]. These changes clearly reflect the European Union and national regulatory bodies and legal stances currently pressuring authorities. An important document relevant to energy efficiency is the European Union Directive 2006/32/EC, which specifies energy end-use efficiency and energy services [107]. Its provisions were ratified on 1 January 2008, and it was deduced that Member States would achieve a reduction in energy consumption of $9 \%$ compared to their baseline level between 2008 and 2016. The requirements of Directive 2006/32/EC imposed an obligation to develop and prepare national plans to achieve these objectives, i.e., Energy Efficiency Action Plans (EEAPs) based on the assumptions of the European Union energy policy [108]. Poland's EEAP includes a description of energy efficiency measures by end-use sectors and calculates final energy savings as an ongoing metric. This plan was developed based on the Energy Efficiency Act of 15 April 2011 [109], which sets out the legal framework for improving energy efficiency, i.e., taking into account the leading role of the public sector and establishing supporting mechanisms and systems for monitoring and collecting the necessary data.

Another important document is ISO 50001, i.e., the guidelines of the energy management system requirements, which was adopted in Poland in 2012 and regulates energy use and consumption according to defined energy usage indicators [110]. In parallel, yet another document adopted the same year was the Directive 2012/27/EU of the European Parliament and of the Council of 25 October 2012 on energy efficiency that established a 
common framework to reduce primary energy consumption in the Union by 20\% [111]. This was an important factor for the success of developing and reaching the European Union's energy strategy by 2020 [111], compelling Poland to achieve an energy savings of $17 \%$ in that year. As a result, its implementation led to the National Law of Energy Efficiency Act of 20 May 2016, imposing widespread energy reform and a national rethinking. Another European Parliament Directive 2018/2002 of 11 December 2018 amended the Directive $2012 / 27$ / EU on energy efficiency by introducing an energy efficiency improvement target of $32.5 \%$ by 2030 [112]. This directive further focalized Poland's energy sector into passing the Compensation System Act of 2019, which introduced a new support system for entities performing business activities in energy-intensive sectors and relating subsectors. These reforms included compensation for transferring the costs of purchasing emission allowances (i.e., within the meaning of the Law on the Greenhouse Gas Emission Trading Scheme) for the price of electricity consumed to produce products by such entities $[113,114]$. At length, this energy advancement highlights a roadmap for other Central and Eastern European countries and firmly presents Poland's ability to diversify its energy use, preventing it from becoming dependent on any one country or energy source (Figure 4) [115].
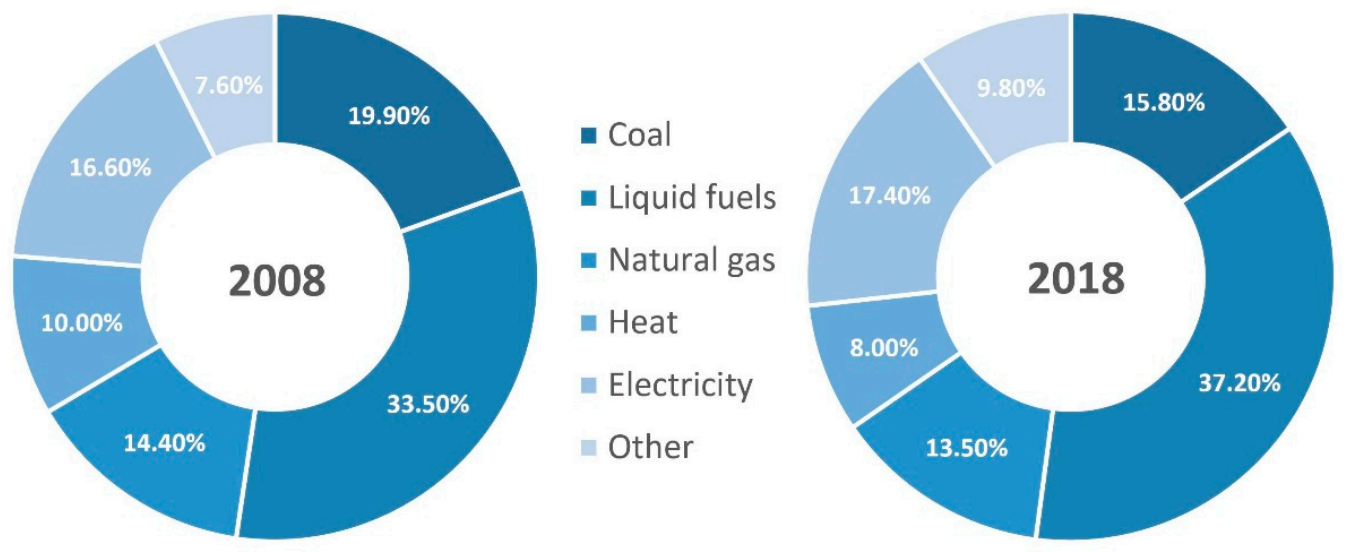

Figure 4. Structure of final energy consumption in Poland by carrier, 2008 and 2018. Source: Peryt et al. [115].

The last decade has brought significant changes and progress in improving energy use in Poland. The energy intensity of its GDP has decreased by nearly 30\%. The greatest impact this has had is on its ability to optimize urban and industrial processes, modernize its lighting systems, and initiate thermomodernization projects throughout the country [108]. The application of effective energy management, specific to city development, still has a number of barriers, some being the lack of widespread use of integrated design of buildings (i.e., from investment) and the implementation of fragmented legal regulations. Other barriers concern the lack of an effective system of financial support for investors to viably participate in the energy-efficiency market, since enterprises and residential construction can lack know-how and awareness of modern technologies. Energy management systems, in accordance with the principles of sustainable development, have had to overcome a number of improvements relating to quality of work, life, and the environment, while still maintaining viable economic outputs [116]. Among the instruments used to improve energy efficiency, horizontal measures include sector-based instruments that regulate energy standards within manufacturing, construction, transport, government, and households. Market mechanisms, which include a system of white certificates, have been implemented to increase energy efficiency in energy generation, transmission, and consumption processes [117]. As such, the market motivator for taking energy efficient action has had a trickle-down effect on consumer behavior, in which end users are more aware of energy consumption and the factors that influence quantity and quality of energy usage [118].

In terms of renewables, Poland, generally, has stood out in high support for the development of these types of energy sources. As many as $87.3 \%$ of Poles support financial support of the state for the creation of new renewable energy production, with only $6.6 \%$ 
in opposition [119]. This support highlights the newly implemented Energy Policy of Poland until 2040 (PEP2040), of which renewable energy sources make up an important component in achieving climate neutrality. On 2 February 2021, the Council of Ministers approved PEP2040 as a new strategy setting a new standard for the development of the sector. PEP2040 directs strategic investment decisions aimed at geopolitically leveraging the economy, raw material, technology, and human resource potential as well as creating, through the energy sector, a lever for the development of the economy to foster equitable transformation [119]. Current targets consist of increasing the share of its renewables in fuel and technology mix to $23 \%$ by 2030 , including up to $32 \%$ net in the power sector, reducing the share of coal in electricity generation to $56 \%$, and reducing GHG emissions by $30 \%$ (relative to 1990), as well as implementing nuclear power by 2050 [120]. Poland's energy policies, over the past two decades, underline an important instance of how a country's ability to change and diversify its energy mix, utilizing European Union standards, has helped it develop its leadership role in Central and Eastern Europe. In comparison to the case research of energy poverty in Ukraine, it is evident that being a member state of the European Union has geopolitical weight that cannot be understated. Geopolitical variables outside of foreign policy and international political behavior include a country's border as well as its bordering countries, climate, demography, natural resources, topography, and scientific capability. In the case of Central and Eastern Europe, Ukraine and Poland illustrate two neighboring countries with two drastically different energy management systems. It is evident that the energy politics of these two countries showcase two different scenarios in terms of energy economics. In terms of the major cities in both countries, it equates to less urban energy output [103] and lower economic levels in Ukraine and more urban energy output [121,122] and higher economic levels in Poland.

\section{Conclusions}

The premise of this essay is to structure important standards in the light of the rural-tourban transition and correlate them with urban energy needs. Three distinct themes were reviewed and inter-related to develop awareness for an urbanizing world that can otherwise appear to have a business-as-usual outlook. The urban population boom continues to pressure the energy dimension with heavily weighted impacts on LDRs. Moving forward, sustainable urban energy will need to be viable, healthy, and environmentally sound [24]. To achieve this, reduced "resource inputs and environmental impacts [will need to be decoupled with] economic growth from energy consumption" [24], e.g., utilizing a closed energy loop form of production and decarbonizing energy resources. Although fossil fuels continue to be the preferred method of energy for cities (and countries by extension), an increased understanding is emerging that sustainable energy forms can supplement them as an alternative. The implementation of renewables in city environments is quickly becoming "energetically imperative" [24] as we incorporate different energy transition processes and look towards a future where energy can be abundant and clean. Such processes will need to be "cost-effective, sustainable, and beneficial for development" [24]. Key to this transition will be the will to invest in renewables (i.e., solar, wind, hydro, tidal, geothermal, and biomass), efficient infrastructure, and smart eco-city designs. As mentioned in our introduction, the process of urbanization can be seen (at first glance) as a challenge, but upon closer examination we believe it to be an opportunity to manage efficient and effective energy designs that can make the future more livable and sustainable. The smart, urban energy transition envisions a new urbanism and city development that interplays between engineering, innovation, and the social sciences [32], with landscape architects and urban designers at the forefront. Our ability to build integrative, technology-based, and energyfriendly components within the physical city will be essential. Renewables side-by-side with green infrastructure will play a crucial role in the smart and sustainable city of the future [36]. Energy-conscious planning and design will be resolution-specific, from the makeup of an entire city to individual building design and microclimates [38]. The internal 
design of cities will allow us to specifically innovate technologies when they become available in best-case scenario-based development.

The technical transition of energy-friendly technologies is focused on understanding how the changes in the energy mix from non-renewable to renewable can be achieved. It is a step from an internal view and design of cities to a technical understanding of energy mix development and models that are not based on facility generation and a distribution network framed around storage systems and feedback loops. A technical transition will incorporate far-reaching concepts, such as smart grids with artificial intelligence that can distribute and store electricity as well as balance production and transmission volumes relative to consumption needs [52]. Ideally, they would operate internationally and alleviate some geopolitical barriers while, at the same time, strengthening partnerships that might otherwise not exist. Technical advancements within energy storage systems have mostly been found in MDRs and are based on a number of different types of battery and capacitor systems. To date, these systems cannot fulfil all energy storage needs $[55,57]$ and should be seen as transitory. As part of this transition, the reduction in emitted pollutants from cities is paramount and backed up by a wide range of (urban) energy mitigation strategies. Urban energy mitigation incorporates legislation from all levels of government, i.e., municipal, national, and international. A number of urban energy functional initiatives for the reduction in GHG emissions from cities work in combination with urban planning and all other aspects discussed in terms of their internal design. By extension, all technical innovation should favor alternative energy technologies to improve and to be effectively implemented. As urban emissions are reduced, important changes environmentally, socially, and economically will become evident, e.g., the implementation of the 3R strategy to reduce, reuse, and recycle could mitigate a waste-to-energy model-based city economy that promotes sustainability and generationally friendly development.

Obviously, policy making will play, in large part, a structural role in which we will entrust leaders to make decisions based on sound scientific discovery and community accord. The geopolitical aspect, from this perspective, seems somewhat childish, since human health and well-being should be considered a given. Nonetheless, as nation states are still heavily reliant on fossil fuels with no permanent end in sight, especially within LDRs, energy management and an economic re-shift—as noted in the case of Central and Eastern Europe-become important hurdles for a common cause. In the case of Ukraine, its energy poverty is compounded by its strong geopolitical troubles. In Poland, since its admission into the European Union, it has become a viable example of energy advancement in Central and Eastern Europe which continues to strongly diversify its total energy mix. The essay's limited case research is used only to elucidate geopolitical complexity and country-specific individuality. Outside the purview of this work, it is fair to state that further case research from around the world is needed. The energy challenges presented in this essay attempt to piece together some of these universal issues that different countries and cities face at the geographical, technological advancement, and economic levels. As such, different nation states face a variety of energy concerns to meet their energy needs. The energy re-shift stressed in the essay veers towards the philosophical (and historical, to some degree), our ability to change and get along with one another. Energy, the life blood of modern cities, should be seen as an opportunity to unite, act responsibly and sustainably, and innovate towards a healthier humanity for a sounder human-energy relationship.

Author Contributions: Conceptualization, visualization, writing—original draft preparation, supervision, project administration, G.T.C.; Methodology, validation, formal analysis, investigation, resources, data curation, writing-review and editing, funding acquisition, G.T.C., A.R., F.B., E.C., A.G.G. and A.O.-J. All authors have read and agreed to the published version of the manuscript.

Funding: This research received no external funding.

Data Availability Statement: All study protocol, documents, and data pertaining to this study are available from the corresponding author on reasonable request. 
Acknowledgments: The authors from the Faculty of Economics at the University of Gdansk, School of Arts at the University of Gloucestershire, and Department of Management at the International Humanitarian University are grateful to the respective institutions for supporting the research and for time allocated to work on the project. Disclaimer. The statements, opinions, and data contained in the work is solely those of the individual authors and may not reflect the opinion of the respected institutions they represent.

Conflicts of Interest: The authors declare no conflict of interest.

\section{Appendix A}

Table A1. Synthesized terms and combinative keyword search used for the methodology.

\begin{tabular}{|c|c|}
\hline Concept & Search Term \\
\hline Rural-to-urban transition & $\begin{array}{l}\text { "urban" OR "urbanization" OR "urban development" } \\
\text { OR "urban population" OR "urban migration" OR "urban sprawl" OR "urban growth" OR } \\
\text { "rural-to-urban" }\end{array}$ \\
\hline $\begin{array}{l}\text { Smart city landscape design and } \\
\text { energy innovation } \\
\text { (internal urban strategies) }\end{array}$ & $\begin{array}{l}\text { AND "smart city" OR "city development" OR "smart agenda" OR "energy sustainability" } \\
\text { OR "energy system" OR "built environment" OR "sustainable city" OR "energy landscape" } \\
\text { OR "landscape design" OR "energy planning" OR "green infrastructure" OR "green walls" } \\
\text { OR "green roof" OR "greenery" OR "edible green infrastructure" OR "urban agriculture" } \\
\text { OR "eco-cities" OR "efficient infrastructure" OR "carbon footprint" }\end{array}$ \\
\hline $\begin{array}{l}\text { Technical transition of energy-friendly technologies } \\
\text { (urban energy mitigation from } \\
\text { non-renewable to renewable) }\end{array}$ & $\begin{array}{l}\text { AND "non-renewable energy" OR "renewable energy" OR "solar power" OR "wind } \\
\text { energy" OR "hydroelectric energy" OR "tidal energy" OR "wave energy" OR "geothermal } \\
\text { energy" OR "biomass energy" OR "power grid" OR "smart grid" OR "electricity storage" } \\
\text { OR “energy balance" OR "energy production" OR "energy transition" OR "alternative } \\
\text { fuel" OR "alternative energy" OR "energy technologies" OR "greenhouse gas emissions" } \\
\text { OR "energy sector" OR "energy initiatives" OR "sustainable energy" }\end{array}$ \\
\hline \multirow{5}{*}{$\begin{array}{c}\text { Geopolitical energy management and the economic } \\
\text { re-shift } \\
\text { (Central and Eastern Europe case research) }\end{array}$} & $\begin{array}{l}\text { AND "geopolitical energy change" OR "energy market" OR "energy management" OR } \\
\text { "energy price" OR "energy economics" OR "energy politics" OR "energy poverty" OR }\end{array}$ \\
\hline & "energy blackouts" OR "energy shortages" OR "energy regulations" OR "energy reform" \\
\hline & OR "energy consumption" OR "price of fossil fuels" OR "energy policy" OR "USA" OR \\
\hline & "Russia" OR "China" OR "Germany" OR “Ukraine" OR "Poland" OR "Central Europe" \\
\hline & "Eastern Europe" OR “European Union" \\
\hline
\end{tabular}

\section{Appendix B}

Table A2. Urban energy function initiatives for the reduction in GHG emissions from cities.

\begin{tabular}{|c|c|c|}
\hline Urban Energy Function & Indicator & References \\
\hline Land use limitation & $\begin{array}{c}\text { Urbanization policy aiming at green areas } \\
\text { establishment and water reservoirs } \\
\text { Green buildings' design codes } \\
\text { Densification with accompanied protected areas and } \\
\text { restricted zones for settlement establishment } \\
\text { Transit-oriented development } \\
\text { Participatory approach to new development } \\
\text { of urban spaces }\end{array}$ & $\begin{array}{c}\text { Cilliers et al. [123]; Di Leo et al. [124]; Kaur and Garg [125]; } \\
\text { Vandermeulen et al. [126] } \\
\text { BMZ [69]; Douglas [127]; UNFCCC [73] } \\
\text { Ali and Al-Kodmany [128]; Lemonsu et al. [129]; } \\
\text { Næss [130] } \\
\text { Chang and Murakami [131]; Mees [132]; Saif et al. [133] } \\
\text { Batty et al. [134]; Ferreira et al. [135]; Jim and Shan [136]; } \\
\text { Russo et al. [137] }\end{array}$ \\
\hline Green buildings & $\begin{array}{c}\text { Global codes and standards for } \\
\text { building implementation } \\
\text { Zero energy through solar photovoltaics and micro } \\
\text { wind turbines } \\
\text { District heating systems based on biomass or } \\
\text { municipal waste } \\
\text { Solar hot water systems } \\
\text { Heat recovery systems } \\
\text { Green roofs and water retention } \\
\text { Municipal auditing, support, and financial }\end{array}$ & $\begin{array}{c}\text { Akbari et al. [138]; C40 Cities et al. [72]; Farr [127] } \\
\text { Buonocore et al. [139]; Hayat et al. [140]; Mancebo [141] } \\
\text { Frick et al. [142]; Patuzzi et al. [143]; Pei-dong et al. [144]; } \\
\text { Tutt and Olt [145] } \\
\text { Chu and Majumdar [146]; Hayat et al. [140]; } \\
\text { Nelson [147] } \\
\text { BMZ [69]; C40 Cities et al. [72]; El-Hawary [55] } \\
\text { Mancebo [141]; Soderlund and Newman [148]; } \\
\text { Tanaka et al. [149]; Thornbush [150] }\end{array}$ \\
\hline
\end{tabular}


Table A2. Cont.

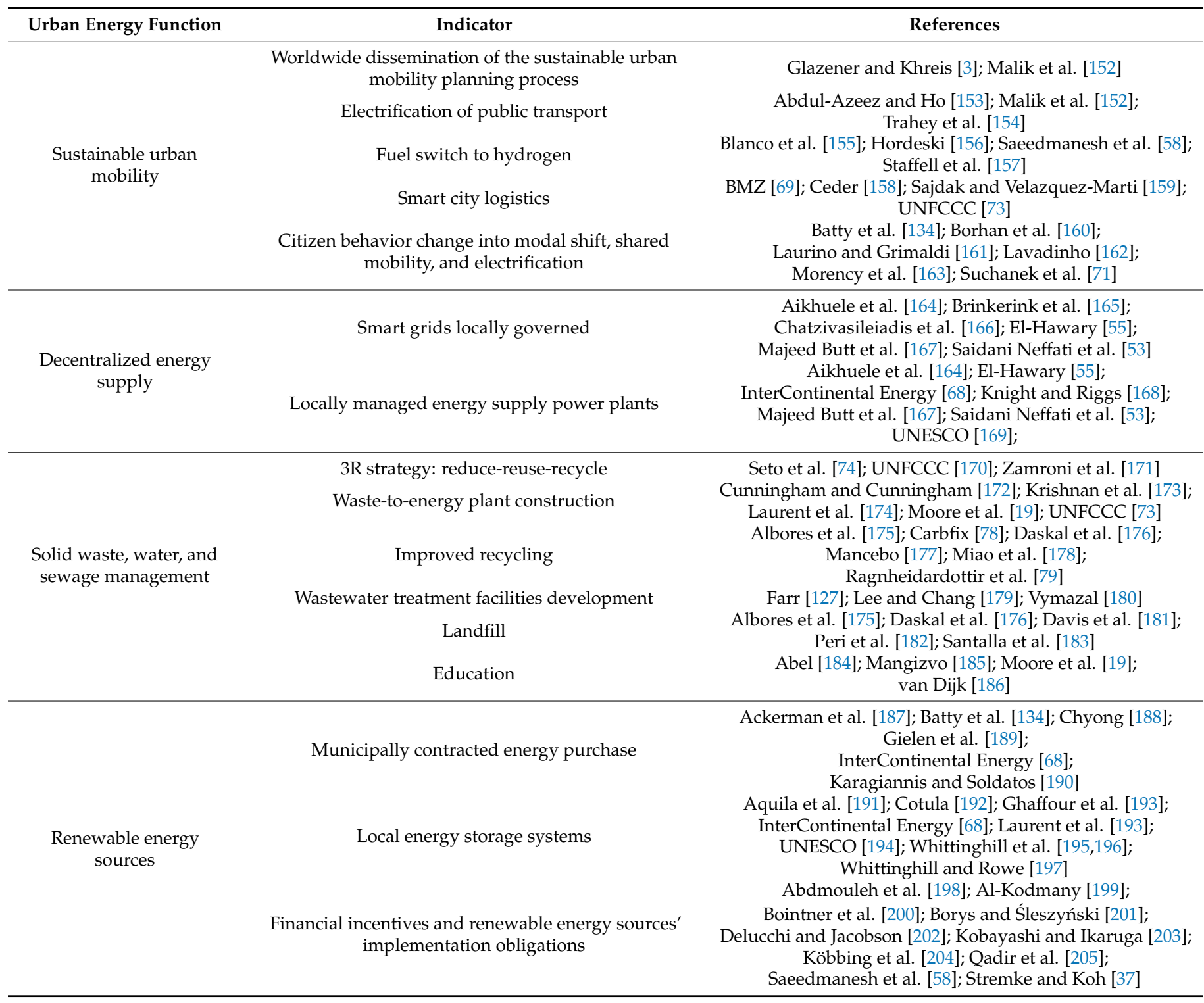

\section{References}

1. UN. World Urbanization Prospects: The 2018 Revision; United Nations, Department of Economic and Social Affairs: New York, NY, USA, 2019

2. Rifkin, J. The Risk of Too Much City; Washington Post: Washington, DC, USA, 2006.

3. Glazener, A.; Khreis, H. Transforming Our Cities: Best Practices towards Clean Air and Active Transportation. Curr. Environ. Heal. Rep. 2019, 6, 22-37. [CrossRef]

4. Chokhachian, A.; Perini, K.; Giulini, S.; Auer, T. Urban performance and density: Generative study on interdependencies of urban form and environmental measures. Sustain. Cities Soc. 2020, 53, 101952. [CrossRef]

5. PRB. 2020 World Population Data Sheet. Available online: https: / interactives.prb.org/2020-wpds (accessed on 26 June 2021).

6. Sassen, S. The Global City; Princeton University Press: New York, NY, USA, 1991.

7. Glaeser, E.L. Triumph of the City: How Our Greatest Invention Makes Us Richer, Smarter, Greener, Healthier and Happier; Penguin: London, UK, 2011.

8. Sigler, T. Book Review: Triumph of the City: How Our Greatest Invention Makes Us Richer, Smarter, Healthier, and Happier. Urban Aff. Rev. 2012, 48, 141-142. [CrossRef]

9. Reiss, D. Review: Triumph of the City: How Our Greatest Invention Makes Us Richer, Smarter, Greener, Healthier, and Happier. Environ. Plan. A Econ. Sp. 2013, 45, 749-750. [CrossRef]

10. Elmqvist, T.; Redman, C.L.; Barthel, S.; Costanza, R. History of urbanization and the missing ecology. In Urbanization, Biodiversity and Ecosystem Services: Challenges and Opportunities: A Global Assessment; Elmqvist, T., Ed.; Springer: Dordrecth, The Netherlands, 2013; pp. 13-30. ISBN 9789400770881. 
11. Davis, K. The Origin and Growth of Urbanization in the World. Am. J. Sociol. 1955, 60, 429-437. [CrossRef]

12. Thompson, W.S. Population. Am. J. Sociol. 1929, 34, 959-975. [CrossRef]

13. Zelinsky, W. The Hypothesis of the Mobility Transition. Geogr. Rev. 1971, 61, 219. [CrossRef]

14. Jacobs, J. Cities and the Wealth of Nations: Principles of Economic Life; Random House: New York, NY, USA, 1984.

15. Gouldson, A.; Colenbrander, S.; Sudmant, A.; Godfrey, N.; Millward-Hopkins, J.; Fang, W.; Zhao, X. Accelerating Low-Carbon Development in the World's Cities; New Climate Economy: London, UK, 2015.

16. Bertinelli, L.; Strobl, E. Urbanisation, urban concentration and economic development. Urban Stud. 2007, 44, 2499-2510. [CrossRef]

17. Pumain, D. The urbanization process. In Demography. Analysis and Synthesis; Caselli, G., Vallin, J., Wunsch, G., Eds.; Elsevier: London, UK, 2006; pp. 319-328.

18. Benassi, F.; Heins, F.; Tucci, E. Residential Migrations in Italian Metropolitan Local Labour Market Areas: Spatial Patterns and Age-Structure Effects. In Moving in Town. Practices, Pathways, and Contexts of Intra-Urban Mobility from 1600 to the Present Day; Canepari, E., Crisci, M., Eds.; Casalini Libri: Fiesole, Italy, 2019; pp. 165-180.

19. Moore, M.; Gould, P.; Keary, B.S. Global urbanization and impact on health. Int. J. Hyg. Environ. Health 2003, 206, 269-278. [CrossRef] [PubMed]

20. Newman, P. The environmental impact of cities. Environ. Urban. 2006, 18, 275-295. [CrossRef]

21. Droege, P. Urban Energy Transition; Elsevier: Oxford, UK, 2008.

22. Riffat, S.; Powell, R.; Aydin, D. Future cities and environmental sustainability. Future Cities Environ. 2016, 2, 1. [CrossRef]

23. Asarpota, K.; Nadin, V. Energy strategies, the Urban dimension, and spatial planning. Energies 2020, 13, 3642. [CrossRef]

24. Phillips, L.; Smith, P. Sustainable Urban Energy Is the Future. UN Chron. 2013, 52, 23-25. [CrossRef]

25. Meyer, W.B. The Environmental Advantages of Cities: Countering Commonsense Antiurbanism; The MIT Press: Cambridge, MA, USA, 2013.

26. Mind Tools Starbursting: Understanding New Ideas by Brainstorming Questions. Available online: https://www.mindtools. com/pages/article/newCT_91.htm (accessed on 14 July 2021).

27. Ritter, S.M.; Mostert, N.M. How to facilitate a brainstorming session: The effect of idea generation techniques and of group brainstorm after individual brainstorm. Creat. Ind. J. 2018, 11, 263-277. [CrossRef]

28. Cirella, G.T.; Bą, M.; Kozlak, A.; Pawłowska, B.; Borkowski, P. Transport innovations for elderly people. Res. Transp. Bus. Manag. 2019, 30, 100381. [CrossRef]

29. Matarese, V. Using strategic, critical reading of research papers to teach scientific writing: The reading-research-writing continuum. In Supporting Research Writing; Elsevier: Amsterdam, The Netherlands, 2013; pp. 73-89.

30. Renear, A.H.; Palmer, C.L. Strategic Reading, Ontologies, and the Future of Scientific Publishing. Science 2009, 325, 828-832. [CrossRef]

31. Broto, V.C. Energy landscapes and urban trajectories towards sustainability. Energy Policy 2017, 108, 755-764. [CrossRef]

32. Haarstad, H.; Wathne, M.W. Are smart city projects catalyzing urban energy sustainability? Energy Policy 2019, 129, 918-925. [CrossRef]

33. Hoang, A.T.; Pham, V.V.; Nguyen, X.P. Integrating renewable sources into energy system for smart city as a sagacious strategy towards clean and sustainable process. J. Clean. Prod. 2021, 305, 127161. [CrossRef]

34. Abu-Rayash, A.; Dincer, I. Development and analysis of an integrated solar energy system for smart cities. Sustain. Energy Technol. Assess. 2021, 46, 101170. [CrossRef]

35. Mozuriunaite, S. The role of landscape design in smart cities. Landsc. Archit. Art 2018, 13, 49-55. [CrossRef]

36. Blaschke, T.; Biberacher, M.; Gadocha, S.; Schardinger, I. 'Energy landscapes': Meeting energy demands and human aspirations. Biomass Bioenergy 2013, 55, 3-16. [CrossRef]

37. Stremke, S.; Koh, J. Integration of Ecological and Thermodynamic Concepts in the Design of Sustainable Energy Landscapes. Landsc. J. 2011, 30, 194-213. [CrossRef]

38. Haque, M.T.; Tai, L.; Ham, D. Landscape Design for Energy Efficiency; Clemson University Digital Press: Clemson, SC, USA, 2004; ISBN 097415167X.

39. European Commission Green Infrastructure in the Energy Sector. 2014. Available online: https://ec.europa.eu/environment/ nature/ecosystems/pdf/Green\%20Infrastructure/GI_energy.pdf (accessed on 10 July 2021).

40. Ko, Y. Trees and vegetation for residential energy conservation: A critical review for evidence-based urban greening in North America. Urban For. Urban Green. 2018, 34, 318-335. [CrossRef]

41. Wang, Z.-H.; Zhao, X.; Yang, J.; Song, J. Cooling and energy saving potentials of shade trees and urban lawns in a desert city. Appl. Energy 2016, 161, 437-444. [CrossRef]

42. McPherson, E.G.; Simpson, J.R. Potential energy savings in buildings by an urban tree planting programme in California. Urban For. Urban Green. 2003, 2, 73-86. [CrossRef]

43. Yuan, S.; Rim, D. Cooling energy saving associated with exterior greenery systems for three US Department of Energy (DOE) standard reference buildings. Build. Simul. 2018, 11, 625-631. [CrossRef]

44. Coma, J.; Pérez, G.; de Gracia, A.; Burés, S.; Urrestarazu, M.; Cabeza, L.F. Vertical greenery systems for energy savings in buildings: A comparative study between green walls and green facades. Build. Environ. 2017, 111, 228-237. [CrossRef]

45. Tan, H.; Hao, X.; Long, P.; Xing, Q.; Lin, Y.; Hu, J. Building envelope integrated green plants for energy saving. Energy Explor. Exploit. 2020, 38, 222-234. [CrossRef] 
46. Kong, F.; Sun, C.; Liu, F.; Yin, H.; Jiang, F.; Pu, Y.; Cavan, G.; Skelhorn, C.; Middel, A.; Dronova, I. Energy saving potential of fragmented green spaces due to their temperature regulating ecosystem services in the summer. Appl. Energy 2016, 183, 1428-1440. [CrossRef]

47. Zhao, M.; Kong, Z.; Escobedo, F.J.; Gao, J. Impacts of urban forests on offsetting carbon emissions from industrial energy use in Hangzhou, China. J. Environ. Manag. 2010, 91, 807-813. [CrossRef] [PubMed]

48. Morabito, P. Green Infrastructure Can Yield Multiple Benefits in an Environmentally-Friendly Way: Three Examples of Green Infrastructure in Action. Available online: https://www.eesi.org/articles/view/green-infrastructure-can-yield-multiple-benefitsin-an-environmentally-frie (accessed on 10 July 2021).

49. Ferla, G.; Caputo, P.; Colaninno, N.; Morello, E. Urban greenery management and energy planning: A GIS-based potential evaluation of pruning by-products for energy application for the city of Milan. Renew. Energy 2020, 160, 185-195. [CrossRef]

50. Neuman, M. Spatial Planning Leadership by Infrastructure: An American View. Int. Plan. Stud. 2009, 14, 201-217. [CrossRef]

51. Hodge, J.; Haltrecht, J. BedZED Seven Years on The Impact of the UK's Best Known Eco-Village and Its Residents; BioRegional: London, UK, 2009.

52. Kougias, I.; Taylor, N.; Kakoulaki, G.; Jäger-Waldau, A. The role of photovoltaics for the European Green Deal and the recovery plan. Renew. Sustain. Energy Rev. 2021, 144, 111017. [CrossRef]

53. Saidani Neffati, O.; Sengan, S.; Thangavelu, K.D.; Dilip Kumar, S.; Setiawan, R.; Elangovan, M.; Mani, D.; Velayutham, P. Migrating from traditional grid to smart grid in smart cities promoted in developing country. Sustain. Energy Technol. Assess. 2021, 45, 101125. [CrossRef]

54. Sioshansi, F.P. Smart Grid: Integrating Renewable, Distributed and Efficient Energy; Elsevier: Amsterdam, The Netherlands, 2012; ISBN 9780-12-38-6452-9.

55. El-Hawary, M.E. The smart grid: State-of-the-art and future trends. Electr. Power Components Syst. 2014, 42, 239-250. [CrossRef]

56. Staffell, I.; Rustomji, M. Maximising the value of electricity storage. J. Energy Storage 2016, 8, 212-225. [CrossRef]

57. Abdelwahab, H.; Moussaid, L.; Moutaouakkil, F.; Medromi, H. Energy Efficiency: Improving the renewable energy penetration in a smart and green community. Procedia Comput. Sci. 2018, 134, 352-357. [CrossRef]

58. Saeedmanesh, A.; Mac Kinnon, M.A.; Brouwer, J. Hydrogen is essential for sustainability. Curr. Opin. Electrochem. 2018, 12, 166-181. [CrossRef]

59. Gul, M.; Kotak, Y.; Muneer, T. Review on recent trend of solar photovoltaic technology. Energy Explor. Exploit. 2016, 34, 485-526. [CrossRef]

60. BP. Statistical Review of World Energy 2020; BP: London, UK, 2020.

61. IRENA. Innovation Landscape for a Renewable-Powered Future; IRENA: Abu Dhabi, United Arab Emirates, 2019.

62. Deng, Y.Y.; Haigh, M.; Pouwels, W.; Ramaekers, L.; Brandsma, R.; Schimschar, S.; Grözinger, J.; de Jager, D. Quantifying a realistic, worldwide wind and solar electricity supply. Glob. Environ. Chang. 2015, 31, 239-252. [CrossRef]

63. Renoald, J.; Hemalatha, V.; Punitha, R.; Sasikala, M.; Sasikala, M.B.E. Solar Roadways-The Future Rebuilding Infrastructure and Economy. Int. J. Electr. Electron. Res. 2016, 4, 14-19.

64. Papadimitriou, C.N.; Psomopoulos, C.S.; Kehagia, F. A review on the latest trend of Solar Pavements in Urban Environment. Energy Procedia 2019, 157, 945-952. [CrossRef]

65. Needell, D.R.; Phelan, M.E.; Hartlove, J.T.; Atwater, H.A. Solar power windows: Connecting scientific advances to market signals Energy 2021, 219, 119567. [CrossRef]

66. Ulavi, T.; Hebrink, T.; Davidson, J.H. Analysis of a Hybrid Solar Window for Building Integration. Energy Procedia 2014, 57, 1941-1950. [CrossRef]

67. Fernández-González, R.; Suárez-García, A.; Feijoo, M.Á.Á.; Arce, E.; Díez-Mediavilla, M. Spanish Photovoltaic Solar Energy: Institutional Change, Financial Effects, and the Business Sector. Sustainability 2020, 12, 1892. [CrossRef]

68. InterContinental Energy. Western Green Energy Hub. Available online: https://intercontinentalenergy.com/western-greenenergy-hub (accessed on 23 July 2021).

69. BMZ. Climate Change Mitigation in Cities: Urban Action to Reduce Greenhouse Gas Emissions; Federal Ministry for Economic Cooperation and Development: Berlin, Germany, 2021.

70. World Resources Institute; C40 Cities Climate Leadership Group; ICLEI-Local Governments for Sustainability. GHG Protocol for Cities; Greenhouse Gas Protocol: Washington, DC, USA, 2014.

71. Suchanek, M.; Jagiełło, A.; Wołek, M. Transport Behaviour in the Context of Shared Mobility. In Challenges of Urban Mobility, Transport Companies and Systems; Suchanek, M., Ed.; Springer: Cham, Switzerland, 2018; pp. 149-158.

72. C40 Cities; Arup; University of Leeds. The Future of Urban Consumption in a $1.5^{\circ} \mathrm{C}$ World C40 Cities: Headline Report; C40 Cities: Washington, DC, USA, 2019.

73. UNFCCC. Urban Environment Related Mitigation Benefits and Co-Benefits of Policies, Practices and Actions for Enhancing Mitigation Ambition and Options for Supporting Their Implementation; United Nations Framework Convention on Climate Change: Bonn, Germany, 2020. 
74. Seto, K.C.; Bigio, A.; Blanco, H.; Carlo Delgado, G.; Bento, A.; Betsill, M.; Bulkeley, H.; Chavez, A.; Cervero, R.; Torres Martinez, J.; et al. Human Settlements, Infrastructure, and Spatial Planning. In Climate Change 2014: Mitigation of Climate Change. Contribution of Working Group III to the Fifth Assessment Report of the Intergovernmental Panel on Climate Change; Edenhofer, O., Pichs-Madruga, R., Sokona, Y., Farahani, E., Kadner, S., Seyboth, K., Adler, A., Baum, I., Brunner, S., Eickemeier, P., et al., Eds.; Cambridge University Press: Cambridge, UK, 2014.

75. Santamouris, M.; Paolini, R.; Haddad, S.; Synnefa, A.; Garshasbi, S.; Hatvani-Kovacs, G.; Gobakis, K.; Yenneti, K.; Vasilakopoulou, K.; Feng, J.; et al. Heat mitigation technologies can improve sustainability in cities. An holistic experimental and numerical impact assessment of urban overheating and related heat mitigation strategies on energy consumption, indoor comfort, vulnerability and heat-related mortality and morbidity in cities. Energy Build. 2020, 217, 110002. [CrossRef]

76. Santamouris, M.; Haddad, S.; Saliari, M.; Vasilakopoulou, K.; Synnefa, A.; Paolini, R.; Ulpiani, G.; Garshasbi, S.; Fiorito, F. On the energy impact of urban heat island in Sydney: Climate and energy potential of mitigation technologies. Energy Build. 2018, 166, 154-164. [CrossRef]

77. Zawadzka, J.E.; Harris, J.A.; Corstanje, R. Assessment of heat mitigation capacity of urban greenspaces with the use of InVEST urban cooling model, verified with day-time land surface temperature data. Landsc. Urban Plan. 2021, 214, 104163. [CrossRef]

78. Carbfix We Turn CO2 Into Stone. Available online: https:/ / www.carbfix.com (accessed on 26 August 2021).

79. Ragnheidardottir, E.; Sigurdardottir, H.; Kristjansdottir, H.; Harvey, W. Opportunities and challenges for CarbFix: An evaluation of capacities and costs for the pilot scale mineralization sequestration project at Hellisheidi, Iceland and beyond. Int. J. Greenh. Gas Control 2011, 5, 1065-1072. [CrossRef]

80. City of Vancouver Climate Emergency Action Plan. Available online: https://vancouver.ca/green-vancouver/vancouversclimate-emergency.aspx (accessed on 14 July 2021).

81. UN Goal 11 I Department of Economic and Social Affairs. Available online: https://sdgs.un.org/goals/goal11 (accessed on 14 July 2021).

82. Non-State Action Zone for Climate Action UNFCCC. Available online: https:// unfccc.int (accessed on 5 July 2021 ).

83. European Commission. Covenant of Mayors for Climate and Energy: Europe. Available online: https://www.covenantofmayors. eu (accessed on 5 July 2021).

84. Ipek, P. Oil and intra-state conflict in Iraq and Syria: Sub-state actors and challenges for Turkey's energy security. Middle East. Stud. 2017, 53, 406-419. [CrossRef]

85. Hurewitz, J.C. Oil, the Arab-Israel Dispute, and the Industrial World: Horizons of Crisis; Routledge: New York, NY, USA, 2019; ISBN 9780367170691.

86. Rosales, A.; Sánchez, M. The Energy Politics of Venezuela. In The Oxford Handbook of Energy Politics; Hancock, K.J., Allison, J.E., Eds.; Oxford University Press: Oxford, UK, 2021; pp. 643-662.

87. Herberg, M.E. Asia's Growing Hunger for Energy: U.S. Policy and Supply Opportunities. Available online: https://www.nbr. org/publication/asias-growing-hunger-for-energy-u-s-policy-and-supply-opportunities (accessed on 24 June 2021).

88. Wang, D. The "Belt and Road" and the Safety of Maritime Energy Transportation Channels. In China-Gulf Oil Cooperation under the Belt and Road Initiative; Springer: Singapore, 2021; pp. 67-108.

89. BBC. Egypt's Suez Canal Blocked by Huge Container Ship. Available online: https://www.bbc.com/news/world-middle-east56505413 (accessed on 24 June 2021).

90. Tabatabai, A.; Esfandiary, D. Triple Axis: Iran's Relations with Russia and China; Bloomsbury Publishing: London, UK, 2020; ISBN 9781788312394.

91. Bolt, P.J.; Cross, S.N. China, Russia, and Twenty-First Century Global Geopolitics; Oxford University Press: Oxford, UK, 2018; ISBN 9780198719519.

92. Zhou, Q.; He, Z.; Yang, Y. Energy geopolitics in Central Asia: China's involvement and responses. J. Geogr. Sci. 2020, 30, 1871-1895. [CrossRef]

93. Zhao, Y.; Liu, X.; Wang, S.; Ge, Y. Energy relations between China and the countries along the Belt and Road: An analysis of the distribution of energy resources and interdependence relationships. Renew. Sustain. Energy Rev. 2019, 107, 133-144. [CrossRef]

94. Mostafaeipour, A.; Alvandimanesh, M.; Najafi, F.; Issakhov, A. Identifying challenges and barriers for development of solar energy by using fuzzy best-worst method: A case study. Energy 2021, 226, 120355. [CrossRef]

95. Alsharif, M.H.; Kim, J.; Kim, J.H. Opportunities and challenges of solar and wind energy in South Korea: A review. Sustainability 2018, 10, 1822. [CrossRef]

96. Sourgens, F.G. The Biden (Energy) Doctrine. ILSA J. Int. Comp. Law 2021, 27, 293-314.

97. BBC. Nord Stream 2: Biden Waives US Sanctions on Russian Pipeline. Available online: https://www.bbc.com/news/world-uscanada-57180674 (accessed on 24 June 2021).

98. Nord Stream 2. Nord Stream 2 Construction. Available online: https://www.nord-stream2.com (accessed on 15 July 2021).

99. Goncharuk, A.G.; lo Storto, C. Challenges and policy implications of gas reform in Italy and Ukraine: Evidence from a benchmarking analysis. Energy Policy 2017, 101, 456-466. [CrossRef]

100. Sziklai, B.R.; Kóczy, L.; Csercsik, D. The impact of Nord Stream 2 on the European gas market bargaining positions. Energy Policy 2020, 144, 111692. [CrossRef]

101. Karpinska, L.; Śmiech, S. Invisible energy poverty? Analysing housing costs in Central and Eastern Europe. Energy Res. Soc. Sci. 2020, 70, 101670. [CrossRef] 
102. Goncharuk, A.G.; Cirella, G.T. A perspective on household natural gas consumption in Ukraine. Extr. Ind. Soc. 2020, 7, 587-592. [CrossRef]

103. Goncharuk, A.G.; Hromovenko, K.V.; Pahlevanzade, A.; Hrinchenko, Y. Energy poverty leap during the pandemic: A case of Ukraine. Polityka Energ. 2021, 24, 5-18. [CrossRef]

104. Bouzarovski, S.; Tirado Herrero, S. The energy divide: Integrating energy transitions, regional inequalities and poverty trends in the European Union. Eur. Urban Reg. Stud. 2017, 24, 69-86. [CrossRef] [PubMed]

105. Bouzarovski, S.; Thomson, H.; Cornelis, M. Confronting Energy Poverty in Europe: A Research and Policy Agenda. Energies 2021, 14, 858. [CrossRef]

106. Leszczyńska, A.; Ki-Hoon, L. Sources and barriers of energy efficiency of Polish enterprises. Ann. Univ. Mariae Curie-Skłodowska Lublin-Polonia 2016, 3, 105-111. [CrossRef]

107. European Parliament. Directive 2006/32/EC of the European Parliament and of the Council of 5 April 2006 on Energy End-Use Efficiency and Energy Services and Repealing Council Directive 93/76/EEC; European Parliament: Brussels, Belgium, 2006.

108. Krawczyk, J.M.; Suwała, W. Directions for improving energy efficiency in Poland. Energy Policy J. 2014, 17, $226-231$.

109. Government of Poland. Law of April 152011 on Energy Efficiency; Government of Poland: Warsaw, Poland, 2011.

110. Malon Group Wdrażanie. ISO 50001-Zarządzanie Energia Obniżające Koszty Zużycia Energii. Available online: https: / /www.iso.org.pl/uslugi-zarzadzania/wdrazanie-systemow/zarzadzanie-srodowiskowe/iso-50001 (accessed on 24 June 2021).

111. European Parliament. Directive 2012/27/EU of the European Parliament and of the Council of 25 October 2012 on Energy Efficiency, Amending Directives 2009/125/EC and 2010/30/EU and Repealing Directives 2004/8/EC and 2006/32/EC Text with EEA Relevance; European Parliament: Brussels, Belgium, 2012.

112. European Parliament. Directive (EU) 2018/2002 of the European Parliament and of the Council of 11 December 2018 Amending Directive 2012/27/EU on Energy Efficiency; European Parliament: Brussels, Belgium, 2018.

113. Government of Poland. Law of July 192019 on the Compensation System for Energy-Intensive Sectors and Subsectors; Government of Poland: Warsaw, Poland, 2019.

114. Energy Regulatory Office. National Report: President of the Energy Regulatory Office; Energy Regulatory Office: Warsaw, Poland, 2020.

115. Peryt, S.; Wnuk, R.; Berent-Kowalska, G.; Nowakowski, P. Energy Efficiency in Poland in Years 2008-2018, Statistical Analyses; Statistics Poland, Polish National Energy Conservation Agency: Warsaw, Poland, 2020.

116. Szczepaniak, K. Energy management system under conditions of sustainable development. J. Manag. Financ. $2014,12,390-401$.

117. Komorowska, A.; Mirowski, T. Instruments for improving energy efficiency in Poland. Zesz. Nauk. Inst. Gospod. Surowcami Miner. Energia Pol. Akad. Nauk. 2016, 92, 300-314.

118. Jovane, F.; Yoshikawa, H.; Alting, L.; Boër, C.R.; Westkamper, E.; Williams, D.; Tseng, M.; Seliger, G.; Paci, A.M. The incoming global technological and industrial revolution towards competitive sustainable manufacturing. CIRP Ann.—Manuf. Technol. 2008, 57, 641-659. [CrossRef]

119. Monitor Polski. Announcement of the Minister of Climate and Environment of 2 March 2021 on the National Energy Policy until 2040; Government of Poland: Warsaw, Poland, 2021.

120. Government of Poland. Sector Analysis: Branch Report; Government of Poland: Warsaw, Poland, 2020.

121. Energy Cities Bielsko-Biala: Where Poland Shows that “Low-Carbon” Is Possible. Available online: https://energy-cities.eu/ bielsko-biala-where-poland-shows-that-low-carbon-is-possible (accessed on 27 August 2021).

122. EIB Poland: The City of Chrzanów Will Build an Eco-District with the Support of the European Investment Advisory Hub. Available online: https:/ / www.eib.org/en/press/all/2021-224-poland-the-city-of-chrzanow-will-build-an-eco-district-withthe-support-of-the-european-investment-advisory-hub (accessed on 26 August 2021).

123. Cilliers, S.; Cilliers, J.; Lubbe, R.; Siebert, S. Ecosystem services of urban green spaces in African countries-Perspectives and challenges. Urban Ecosyst. 2013, 16, 681-702. [CrossRef]

124. Di Leo, N.; Escobedo, F.J.; Dubbeling, M. The role of urban green infrastructure in mitigating land surface temperature in Bobo-Dioulasso, Burkina Faso. Environ. Dev. Sustain. 2016, 18, 373-392. [CrossRef]

125. Kaur, H.; Garg, P. Urban sustainability assessment tools: A review. J. Clean. Prod. 2019, 210, 146-158. [CrossRef]

126. Vandermeulen, V.; Verspecht, A.; Vermeire, B.; Van Huylenbroeck, G.; Gellynck, X. The use of economic valuation to create public support for green infrastructure investments in urban areas. Landsc. Urban Plan. 2011, 103, 198-206. [CrossRef]

127. Farr, D. Sustainable Urbanism: Urban Design with Nature; Wiley: New Jersey, NJ, USA, 2012; ISBN 1118174518.

128. Ali, M.M.; Al-Kodmany, K. Tall Buildings and Urban Habitat of the 21st Century: A Global Perspective. Buildings 2012, 2, 384-423. [CrossRef]

129. Lemonsu, A.; Viguié, V.; Daniel, M.; Masson, V. Vulnerability to heat waves: Impact of urban expansion scenarios on urban heat island and heat stress in Paris (France). Urban Clim. 2015, 14, 586-605. [CrossRef]

130. Næss, P. Urban Form, Sustainability and Health: The Case of Greater Oslo. Eur. Plan. Stud. 2014, 22, 1524-1543. [CrossRef]

131. Chang, Z.; Murakami, J. Transferring land-use rights with transportation infrastructure extensions: Evidence on spatiotemporal price formation in Shanghai. J. Transp. Land Use 2019, 12, 1-19. [CrossRef]

132. Mees, P. TOD and Multi-modal Public Transport. Plan. Pract. Res. 2014, 29, 461-470. [CrossRef]

133. Saif, M.A.; Zefreh, M.M.; Torok, A. Public transport accessibility: A literature review. Period. Polytech. Transp. Eng. 2019, 47, 36-43. [CrossRef] 
134. Batty, M.; Axhausen, K.W.; Giannotti, F.; Pozdnoukhov, A.; Bazzani, A.; Wachowicz, M.; Ouzounis, G.; Portugali, Y. Smart cities of the future. Eur. Phys. J. Spec. Top. 2012, 214, 481-518. [CrossRef]

135. Ferreira, A.J.D.; Guilherme, R.I.M.M.; Ferreira, C.S.S.; Oliveira, M.D.F.M.L. Urban agriculture, a tool towards more resilient urban communities? Curr. Opin. Environ. Sci. Health 2018, 5, 93-97. [CrossRef]

136. Jim, C.Y.; Shan, X. Socioeconomic effect on perception of urban green spaces in Guangzhou, China. Cities 2013, 31, 123-131. [CrossRef]

137. Russo, A.; Chan, W.T.; Cirella, G.T. Estimating Air Pollution Removal and Monetary Value for Urban Green Infrastructure Strategies Using Web-Based Applications. Land 2021, 10, 788. [CrossRef]

138. Akbari, H.; Pomerantz, M.; Taha, H. Cool surfaces and shade trees to reduce energy use and improve air quality in urban areas Sol. Energy 2001, 70, 295-310. [CrossRef]

139. Buonocore, J.J.; Hughes, E.J.; Michanowicz, D.R.; Heo, J.; Allen, J.G.; Williams, A. Climate and health benefits of increasing renewable energy deployment in the United States. Environ. Res. Lett. 2019, 14, 114010. [CrossRef]

140. Hayat, M.B.; Ali, D.; Monyake, K.C.; Alagha, L.; Ahmed, N. Solar energy-A look into power generation, challenges, and a solar-powered future. Int. J. Energy Res. 2019, 43, 1049-1067. [CrossRef]

141. Mancebo, F. Urban Agriculture for Urban Regeneration in the Sustainable City. In Quality of Life in Urban Landscapes; Grifoni, R.C., D'Onofrio, R., Sargolini, M., Eds.; Springer: Cham, Switzerland, 2018; pp. 311-317.

142. Frick, A.; Steffenhagen, P.; Zerbe, S.; Timmermann, T.; Schulz, K. Monitoring of the vegetation composition in rewetted peatland with iterative decision tree classification of satellite imagery. Photogramm. Fernerkund. Geoinf. 2011, 2011, 109-122. [CrossRef]

143. Patuzzi, F.; Mimmo, T.; Cesco, S.; Gasparella, A.; Baratieri, M. Common reeds (Phragmites australis) as sustainable energy source: Experimental and modelling analysis of torrefaction and pyrolysis processes. GCB Bioenergy 2013, 5, 367-374. [CrossRef]

144. Pei-dong, Z.; Guomei, J.; Gang, W. Contribution to emission reduction of $\mathrm{CO}_{2}$ and $\mathrm{SO}_{2}$ by household biogas construction in rural China. Renew. Sustain. Energy Rev. 2007, 11, 1903-1912. [CrossRef]

145. Tutt, M.; Olt, J. Suitability of various plant species for bioethanol production. Agron. Res. 2011, 9, $261-267$.

146. Chu, S.; Majumdar, A. Opportunities and challenges for a sustainable energy future. Nature 2012, 488, 294-303. [CrossRef] [PubMed]

147. Nelson, V. Introduction to Renewable Energy; Ghassemi, A., Ed.; CRC Press: Boca Raton, FL, USA, 2011 ; ISBN 1439834504.

148. Soderlund, J.; Newman, P. Biophilic architecture: A review of the rationale and outcomes. AIMS Environ. Sci. 2015, 2, 950-969. [CrossRef]

149. Tanaka, Y.; Kawashima, S.; Hama, T.; Sánchez Sastre, L.F.; Nakamura, K.; Okumoto, Y. Mitigation of heating of an urban building rooftop during hot summer by a hydroponic rice system. Build. Environ. 2016, 96, 217-227. [CrossRef]

150. Thornbush, M. Urban agriculture in the transition to low carbon cities through urban greening. AIMS Environ. Sci. 2015, 2, 852-867. [CrossRef]

151. Ardiwijaya, V.S.; Sumardi, T.P.; Suganda, E.; Temenggung, Y.A. Rejuvenating Idle Land to Sustainable Urban form: Case Study of Bandung Metropolitan Area, Indonesia. Procedia Environ. Sci. 2015, 28, 176-184. [CrossRef]

152. Malik, Y.; Prakash, N.; Kapoor, A. Green transport: A way forward for environmental sustainability. In Research in Political Sociology; Emerald Group Publishing Ltd.: London, UK, 2018; Volume 25, pp. 163-180. ISBN 978-1-78714-776-8.

153. Abdul-Azeez, I.A.; Ho, C.S. Realizing Low Carbon Emission in the University Campus towards Energy Sustainability. Open J. Energy Effic. 2015, 4, 15-27. [CrossRef]

154. Trahey, L.; Brushett, F.R.; Balsara, N.P.; Ceder, G.; Cheng, L.; Chiang, Y.M.; Hahn, N.T.; Ingram, B.J.; Minteer, S.D.; Moore, J.S.; et al. Energy storage emerging: A perspective from the Joint Center for Energy Storage Research. Proc. Natl. Acad. Sci. USA 2020, 117, 12550-12557. [CrossRef]

155. Blanco, H.; Nijs, W.; Ruf, J.; Faaij, A. Potential for hydrogen and Power-to-Liquid in a low-carbon EU energy system using cost optimization. Appl. Energy 2018, 232, 617-639. [CrossRef]

156. Hordeski, M.F. Alternative Fuels: The Future of Hydrogen; Fairmont Press: Lilburn, GA, USA, 2008 ; ISBN 0881735965.

157. Staffell, I.; Scamman, D.; Velazquez Abad, A.; Balcombe, P.; Dodds, P.E.; Ekins, P.; Shah, N.; Ward, K.R. The role of hydrogen and fuel cells in the global energy system. Energy Environ. Sci. 2019, 12, 463-491. [CrossRef]

158. Ceder, A. Urban mobility and public transport: Future perspectives and review. Int. J. Urban Sci. 2020, 1-25. [CrossRef]

159. Sajdak, M.; Velazquez-Marti, B. Estimation of pruned biomass form dendrometric parameters on urban forests: Case study of Sophora japonica. Renew. Energy 2012, 47, 188-193. [CrossRef]

160. Borhan, M.N.; Syamsunur, D.; Mohd Akhir, N.; Mat Yazid, M.R.; Ismail, A.; Rahmat, R.A. Predicting the use of public transportation: A case study from Putrajaya, Malaysia. Sci. World J. 2014, 2014, 1-9. [CrossRef]

161. Laurino, A.; Grimaldi, R. The Italian Way to Carsharing. TeMA J. Land Use Mobil. Environ. 2012, 5, 77-90. [CrossRef]

162. Lavadinho, S. Public transport infrastructure and walking: Gearing towards the multimodal city. In Transport and Sustainability; Emerald Group Publishing Ltd.: London, UK, 2017; Volume 9, pp. 167-186. ISBN 978-1-78714-628-0.

163. Morency, C.; Habib, K.M.N.; Grasset, V.; Islam, M.T. Understanding members' carsharing (activity) persistency by using econometric model. J. Adv. Transp. 2012, 46, 26-38. [CrossRef]

164. Aikhuele, D.O.; Ighravwe, D.E.; Akinyele, D. Evaluation of Renewable Energy Technology Based on Reliability Attributes Using Hybrid Fuzzy Dynamic Decision-Making Model. Technol. Econ. Smart Grids Sustain. Energy 2019, 4, 1-7. [CrossRef] 
165. Brinkerink, M.; Gallachóir, B.; Deane, P. A comprehensive review on the benefits and challenges of global power grids and intercontinental interconnectors. Renew. Sustain. Energy Rev. 2019, 107, 274-287. [CrossRef]

166. Chatzivasileiadis, S.; Ernst, D.; Andersson, G. The Global Grid. Renew. Energy 2013, 57, 372-383. [CrossRef]

167. Majeed Butt, O.; Zulqarnain, M.; Majeed Butt, T. Recent advancement in smart grid technology: Future prospects in the electrical power network. Ain Shams Eng. J. 2020, in press. [CrossRef]

168. Knight, L.; Riggs, W. Nourishing urbanism: A case for a new urban paradigm. Int. J. Agric. Sustain. 2010, 8, 116-126. [CrossRef]

169. UNESCO. The United Nations World Water Development Report 3: Water in a Changing World. In World Water Assessment Programme; Earthscan, Ed.; UNESCO: Paris, France, 2009; Volume 3, p. 349. ISBN 9789231042355.

170. UNFCCC. United Nations: Climate Change. Available online: https:/ / unfccc.int (accessed on 14 February 2021).

171. Zamroni, M.; Prahara, R.S.; Kartiko, A.; Purnawati, D.; Kusuma, D.W. The Waste Management Program Of 3R (Reduce, Reuse, Recycle) By Economic Incentive and Facility Support. J. Phys. Conf. Ser. 2020, 1471, 12048. [CrossRef]

172. Cunningham, W.P.; Cunningham, M.A. Principles of Environmental Science: Inquiry and Applications; McGraw-Hill: New York, NY, USA, 2006; ISBN 0073019267.

173. Krishnan, R.; Geyskens, I.; Steenkamp, J.B.E.M. The effectiveness of contractual and trust-based governance in strategic alliances under behavioral and environmental uncertainty. Strateg. Manag. J. 2016, 37, 2521-2542. [CrossRef]

174. Laurent, A.; Bakas, I.; Clavreul, J.; Bernstad, A.; Niero, M.; Gentil, E.; Hauschild, M.Z.; Christensen, T.H. Review of LCA studies of solid waste management systems-Part I: Lessons learned and perspectives. Waste Manag. 2014, 34, 573-588. [CrossRef]

175. Albores, P.; Petridis, K.; Dey, P.K. Analysing Efficiency of Waste to Energy Systems: Using Data Envelopment Analysis in Municipal Solid Waste Management. Procedia Environ. Sci. 2016, 35, 265-278. [CrossRef]

176. Daskal, S.; Ayalon, O.; Shechter, M. The state of municipal solid waste management in Israel. Waste Manag. Res. 2018, 36, 527-534. [CrossRef] [PubMed]

177. Mancebo, F. Gardening the City: Addressing Sustainability and Adapting to Global Warming through Urban Agriculture. Environments 2018, 5, 38. [CrossRef]

178. Miao, C.; Fang, D.; Sun, L.; Luo, Q. Natural resources utilization efficiency under the influence of green technological innovation. Resour. Conserv. Recycl. 2017, 126, 153-161. [CrossRef]

179. Lee, C.-S.; Chang, S.-P. Interactive fuzzy optimization for an economic and environmental balance in a river system. Water Res. 2005, 39, 221-231. [CrossRef]

180. Vymazal, J. Constructed wetlands for wastewater treatment. Water 2010, 2, 530-549. [CrossRef]

181. Davis, G.; Phillips, P.S.; Read, A.D.; Iida, Y. Demonstrating the need for the development of internal research capacity: Understanding recycling participation using the Theory of Planned Behaviour in West Oxfordshire, UK. Resour. Conserv. Recycl. 2006, 46, 115-127. [CrossRef]

182. Peri, G.; Traverso, M.; Finkbeiner, M.; Rizzo, G. The cost of green roofs disposal in a life cycle perspective: Covering the gap. Energy 2012, 48, 406-414. [CrossRef]

183. Santalla, E.; Córdoba, V.; Blanco, G. Greenhouse gas emissions from the waste sector in Argentina in business-as-usual and mitigation scenarios. J. Air Waste Manag. Assoc. 2013, 63, 909-917. [CrossRef]

184. Abel, A. An analysis of solid waste generation in a traditional African city: The example of Ogbomoso, Nigeria. Environ. Urban. 2007, 19, 527-537. [CrossRef]

185. Mangizvo, R.V. Challenges of Solid Waste Management in the Central Business District of the City of Gweru in Zimbabwe. J. Sustain. Dev. 2007, 9, 134-145.

186. Van Dijk, M.P. Three Ecological Cities, Examples of Different Approaches in Asia and Europe. In Eco-City Planning; Wong, T.-C., Yuen, B., Eds.; Springer: Dordrecht, The Netherlands, 2011; pp. 31-50. ISBN 978-94-007-0383-4.

187. Ackerman, K.; Conard, M.; Culligan, P.; Plunz, R.; Sutto, M.P.; Whittinghill, L. Sustainable food systems for future cities: The potential of urban agriculture. Econ. Soc. Rev. 2014, 45, 189-206.

188. Chyong, C.K. European Natural Gas Markets: Taking Stock and Looking Forward. Rev. Ind. Organ. 2019, 55, 89-109. [CrossRef]

189. Gielen, D.; Boshell, F.; Saygin, D.; Bazilian, M.D.; Wagner, N.; Gorini, R. The role of renewable energy in the global energy transformation. Energy Strateg. Rev. 2019, 24, 38-50. [CrossRef]

190. Karagiannis, I.C.; Soldatos, P.G. Estimation of critical $\mathrm{CO}_{2}$ values when planning the power source in water desalination: The case of the small Aegean islands. Energy Policy 2010, 38, 3891-3897. [CrossRef]

191. Aquila, G.; Pamplona, E.D.O.; Queiroz, A.R.D.; Rotela Junior, P.; Fonseca, M.N. An overview of incentive policies for the expansion of renewable energy generation in electricity power systems and the Brazilian experience. Renew. Sustain. Energy Rev. 2017, 70, 1090-1098. [CrossRef]

192. Cotula, L. The international political economy of the global land rush: A critical appraisal of trends, scale, geography and drivers. J. Peasant Stud. 2012, 39, 649-680. [CrossRef]

193. Ghaffour, N.; Missimer, T.M.; Amy, G.L. Technical review and evaluation of the economics of water desalination: Current and future challenges for better water supply sustainability. Desalination 2013, 309, 197-207. [CrossRef]

194. UNESCO. The United Nations World Water Development Report 4: Managing Water under Uncertainty and Risk. In World Water Assessment Programme; Earthscan, Ed.; UNESCO: Paris, France, 2012; Volume 1, p. 407. ISBN 9789231042355.

195. Whittinghill, L.J.; Rowe, D.B.; Schutzki, R.; Cregg, B.M. Quantifying carbon sequestration of various green roof and ornamental landscape systems. Landsc. Urban Plan. 2014, 123, 41-48. [CrossRef] 
196. Whittinghill, L.J.; Rowe, D.B.; Andresen, J.A.; Cregg, B.M. Comparison of stormwater runoff from sedum, native prairie, and vegetable producing green roofs. Urban Ecosyst. 2014, 18, 13-29. [CrossRef]

197. Whittinghill, L.J.; Rowe, D.B. The role of green roof technology in urban agriculture. Renew. Agric. Food Syst. 2012, 27, 314-322. [CrossRef]

198. Abdmouleh, Z.; Alammari, R.A.M.; Gastli, A. Review of policies encouraging renewable energy integration \& best practices. Renew. Sustain. Energy Rev. 2015, 45, 249-262. [CrossRef]

199. Al-Kodmany, K. Green towers and iconic design: Cases from three continents. Archnet-IJAR Int. J. Archit. Res. 2014, 8, 11-28. [CrossRef]

200. Bointner, R.; Pezzutto, S.; Grilli, G.; Sparber, W. Financing innovations for the renewable energy transition in Europe. Energies 2016, 9, 990. [CrossRef]

201. Borys, T.; Śleszyński, J. Ekorozwój jako zbiór zasad. In Wskaźniki Ekorozwoju. Wydawnictwo Ekonomia i Środowisko; Borys, T., Ed.; Foundation of Environmental and Resource Economists: Białystok, Poland, 1999; pp. 85-92.

202. Delucchi, M.A.; Jacobson, M.Z. Providing all global energy with wind, water, and solar power, Part II: Reliability, system and transmission costs, and policies. Energy Policy 2011, 39, 1170-1190. [CrossRef]

203. Kobayashi, T.; Ikaruga, S. Development of a smart city planning support tool using the cooperative method. Front. Archit. Res. 2015, 4, 277-284. [CrossRef]

204. Köbbing, J.F.; Thevs, N.; Zerbe, S. The utilisation of Reed (Phragmites australis) -A review. Mires Peat 2013, 13, 1-14.

205. Qadir, S.A.; Al-Motairi, H.; Tahir, F.; Al-Fagih, L. Incentives and strategies for financing the renewable energy transition: A review. Energy Reports 2021, 7, 3590-3606. [CrossRef] 